\title{
Oocyte Follicle Cells Association during Development of Human Ovarian Follicle. A Study by High Resolution Scanning and Transmission Electron Microscopy*
}

\author{
Pietro M. MotTA ${ }^{1}$, Sayoko MAKABE ${ }^{2}$, Tomonori NAGUR0 ${ }^{3}$ and Silvia CorRer ${ }^{1}$ \\ Department of Anatomy ${ }^{1}$, Faculty of Medicine, University of Rome "La Sapienza”, Rome, Italy: Department of Gynecology², \\ Toho University School of Medicine, Tokyo; and Department of Anatomy ${ }^{3}$, Faculty of Medicine, Tottori University, Yonago, \\ Japan
}

Received July 28, 1994

Summary. Morphodynamics of oocyte follicle cells association during the development of human ovarian follicles were studied by transmission electron microscopy and high resolution scanning electron microscopy including the ODO method.

For this study primordial, primary, growing preantral and antral follicles were systematically analysed in a total of 20 adult and fetal (3-8 months and at term) ovaries.

In early stages of follicle development (primordial and primary stages) the flattened and/or polyhedral cells, closely associated with the growing oocyte, project an increasing number of microvillous processes. These are in apposition with the oolemma, and form bulbous terminals presenting attachment zones such as zonula adherens, desmosomes and communicating junctions (gap junctions). "Focal contacts" between oolemma, and lateral microvillous extensions of follicle cells were also present.

Unusual forms of contact between follicle cell microvilli and oocytes in the early stages of growing primordial and primary follicles were also observed. These consist of long, thin extensions penetrating into the oocyte through deep invaginations of the oolemma. The aid of high resolution SEM of specimens subjected to the ODO method clearly reveals their 3-D arrangement within the ooplasm. They appear as long tortuous microvilli coming very close to the nucleus, and in their course are closely associated with a variety of organelles such as Golgi vesicles, endoplasmic reticulum membranes and nascent forms of smooth endoplasmic reticulum.

Using integrated observations by TEM and SEM, there may be as many as 3-5 "intraooplasmic processes" even in only one plane of fracture of an oocyte. There- fore, if the total volume of the oocyte and associated cells is considered, their amounts appear to be higher than previously reported. Thus, they have to be considered as normal devices of deep contact between the ooplasm and associated follicle cell extensions.

The presence of such structures within the ooplasm in early developing follicles well coincides with the great increase in volume of the oocyte. Although it is commonly believed that the activation of the growing oocyte may depend on the numerous contacts between the oolemma and follicle cells (mostly via gap junctions), the finding of these additional intraoocytic extensions suggests that they may in someway contribute to the initiation of growth in the human. In fact, these microvilli penetrate deep into the ooplasm, much like a sword in its sheath. After contacting numerous oocytes' organelles, they come close to the nucleus, where they might transfer, more extensively and easily, a variety of ions or molecules (as signals), including nutrients. In turn, they may mediate or integrate a parallel activation on specific oocyte organelles and their cohort of enzymes.

In later stages of follicle development (pluristratified and antral follicles provided with a thick and complete zona pellucida), these intraooplasmic microvilli were very rarely observed. In large antral follicles close to ovulation, the bulbous processes of follicle cells contacting the oolemma were noted, and the attachement zones (zonula adherens, desmosome) and gap junctions appeared very numerous. All these junctions disappear by being disrupted, at the time of ovulation, by active retraction of follicle cell extensions.

The long exposure of specimens to the ODO maceration method allowed full observation of the real 3-D

*Preliminary results of this work have been presented at Xth International Symposium on Morphological Sciences, Toronto-Canada, July 1-5, 1991 in the Symposium 3-D Microanatomy of Cells and Tissue by SEM in honor of Prof. K. TANAKA 
surface pattern of follicular cells and their extensions, including those of the so-called corona radiata. In fact, through the chemical dissolution of liquor folliculi and zona pellucida, these cells, which were mainly pear shaped, showed a characteristic apical polarization of their numerous microvilli toward the oocyte. As a rule, these unusual microvilli measured $7-10 \mu \mathrm{m}$ in length and the apical surface of a single corona cell toward the zone/ oocyte formed up to 70 long microvilli. Similar extensions were rarely observed over the remaining surfaces of the corona cells facing the antrum, or over the surface of associated cumulus and parietal follicular cells. Single short cilia were also frequently noted in these cells.

As fully revealed by SEM following the ODO method, these microvilli contribute to a tremendous increase in the surface area of corona cells containing the oocyte. In fact, anchored as bridges to the oolemma, they provide a sort of cytoplasmic skeleton supporting the zona pellucida. As revealed by their 3 -D pattern, addi- tional functions for these structures may be suggested:

1) transfer of substances to build up the zona pellucida; 2) release of nutrients into the zona and from there to the oocyte, and vice versa; and 3) removal of catabolites from the zona, as well as from the oocyte.

Thus the zona, which closely resembles a thick basal lamina, can be continuosly regenerated, acting as an efficient filter for the oocyte.

A final consideration that these 3 -D images suggest is that in vivo the corona cell extensions are included in the zona pellucida. Therefore, narrow spaces separate the dense channels sculptured in the zona from the surface of cytoplasmic processes of corona cells contained therein. As a consequence, a kind of microlabyrinthine system of microfissures (microtunnels) arises, which may serve as areas of exchange of minute materials to/from the follicle cell, the oocyte and zona pellucida. Further considering that follicular cells and their extensions are highly pulsatile in nature because of the high number of contractile filaments, the obvious deduction is that in

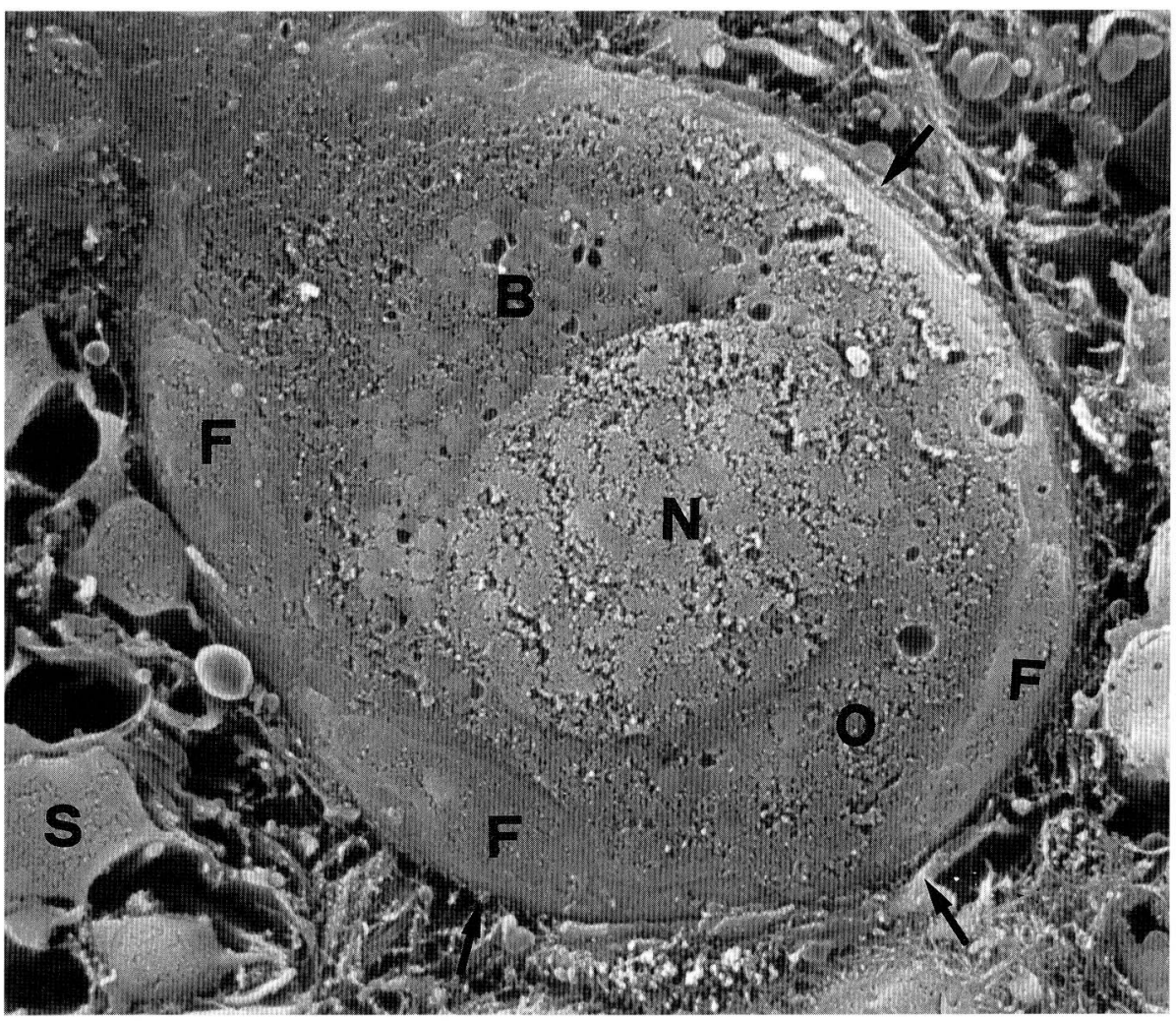

Fig. 1. Primordial follicle of an 18 -week fetal human ovary. The oocyte $(O)$ which is invested by a single layer of flattened cells $(F)$, is large and has an ovoid ooplasm and nucleus $(N)$. In the ooplasm close to nuclear surface is a mass of spherical organelles and irregular membranes corresponding to mitochondria, elements of the Golgi complex, endoplasmic reticulum, lysosomes, lipids and often the annulate lamellae. This structure corresponds to the so called "Balbiani vitelline body" $(B)$ (HERTIG and ADAMS, 1967). A thin and regular basal lamina (arrows) separates the follicle from the numerous stroma cells $(S)$. SEM preparation obtained by razor blade. $\times 3,000$ 
vivo, the follicular cell extensions may elongate and retract continuously within the microtunnels of the solidified zona pellucida. Therefore, the numerous contacts that they have with the oocyte may be not permanent but dynamic, with high functional advantages. In particular, it is possible to hypothesize that a variety of dynamic contacts are created between follicular cells and oocytes and among microvilli of corona cells. These in turn may serve to actively modulate (inhibiting or stimulating) the oocyte up until the time of ovulation through a coordination with the entire follicle oocyte complex.

The relationship between oocytes and follicular cells has been extensively studied by means of electron microscopy in different mammals, including humans (WARTENBERG and STEGNER, 1960; BACA and ZAMBONI, 1967; Hertig and AdAMs, 1967; MotTA and VAN BlerKom,
1979; DVORAK and TESARIK, 1980; SATHANANTHAN et al., 1986). In particular, these two cell types are associated primarily by means of numerous long follicular cell projections and microvilli which are in close contact with the oocyte (SOTELO and PORTER, 1959; CHIQUOINE, 1960; ZAMBOnI, 1974; DvOrAK and TESARIK, 1980; SATHANANTHAN et al., 1986). In addition, considerable evidence has been accumulated showing that gap junctions, as well as other junctional complexes (tight junction; zonula adherens, desmosome), form the major anchorage between the oocyte and follicular cell plasma membranes during all stages of follicle development (MotTA et al., 1971a; Albertini and Anderson, 1974; Gilula, 1977; EPPIG, 1982).

Once these intercellular bridges are established in early developing follicles, they increase progressively in number but remain basically unaltered until the time of full oocyte maturation when meiosis resumes

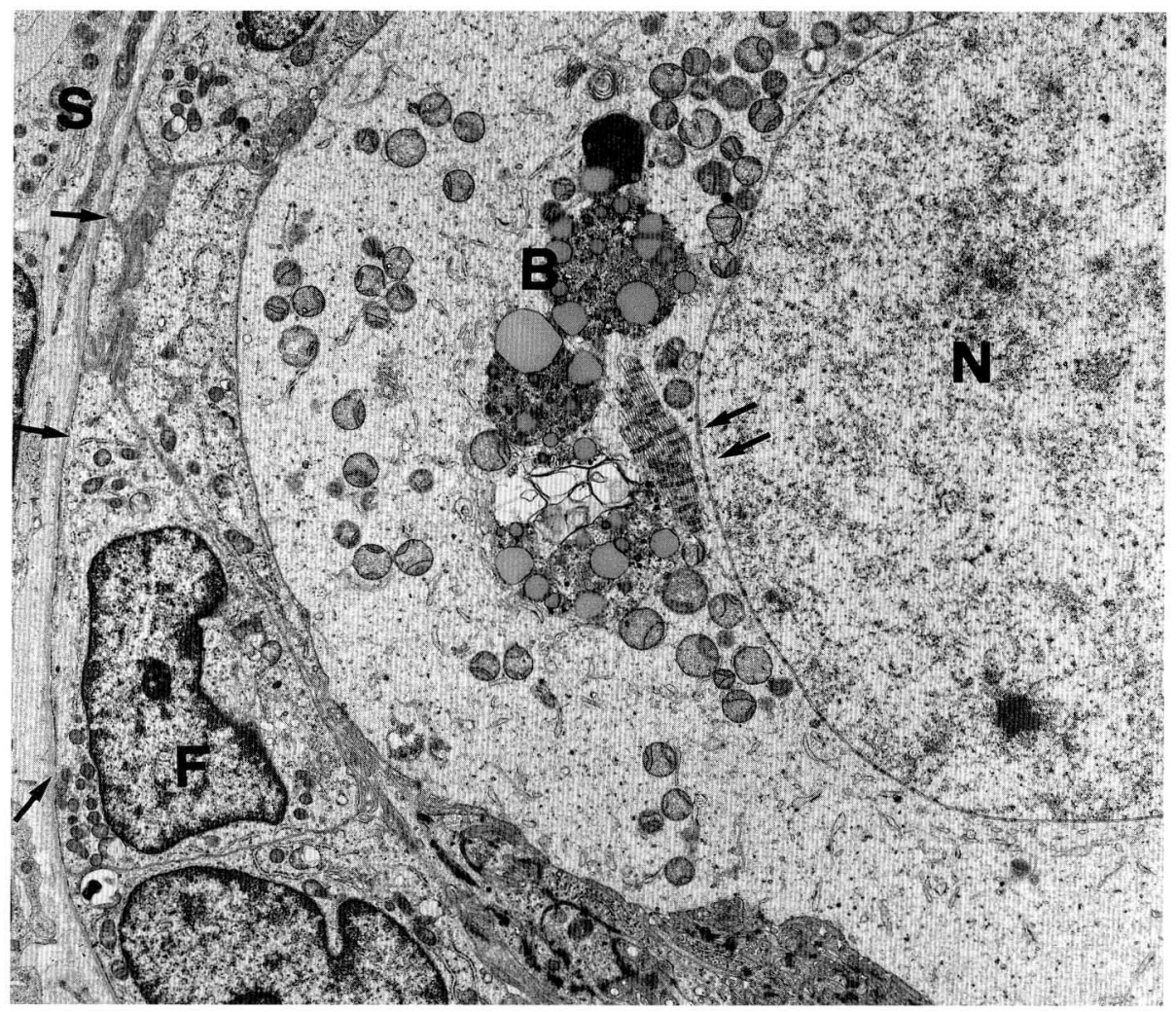

Fig. 2. Primordial follicle of an adult ovary from a young woman (28 years old). The oocyte, encircled by one layer of thin follicular cells $(F)$, shows a large nucleus $(N)$. The outer aspect of the follicle is separated from the interstitial cellular stroma $(S)$ by a thin but continuous basal lamina (arrows). In an area close to the nucleus there is evidently a large conglomerate of mitochondria, lipid droplets, lysosomes, Golgi and endoplasmic reticulum membranes and a characteristic stack of annulate lamellae (double arrows). This mass is the so called "Balbiani vitelline body" $(B)$ similar to that viewed by SEM in Figure 1. TEM; $\times 4,000$ 

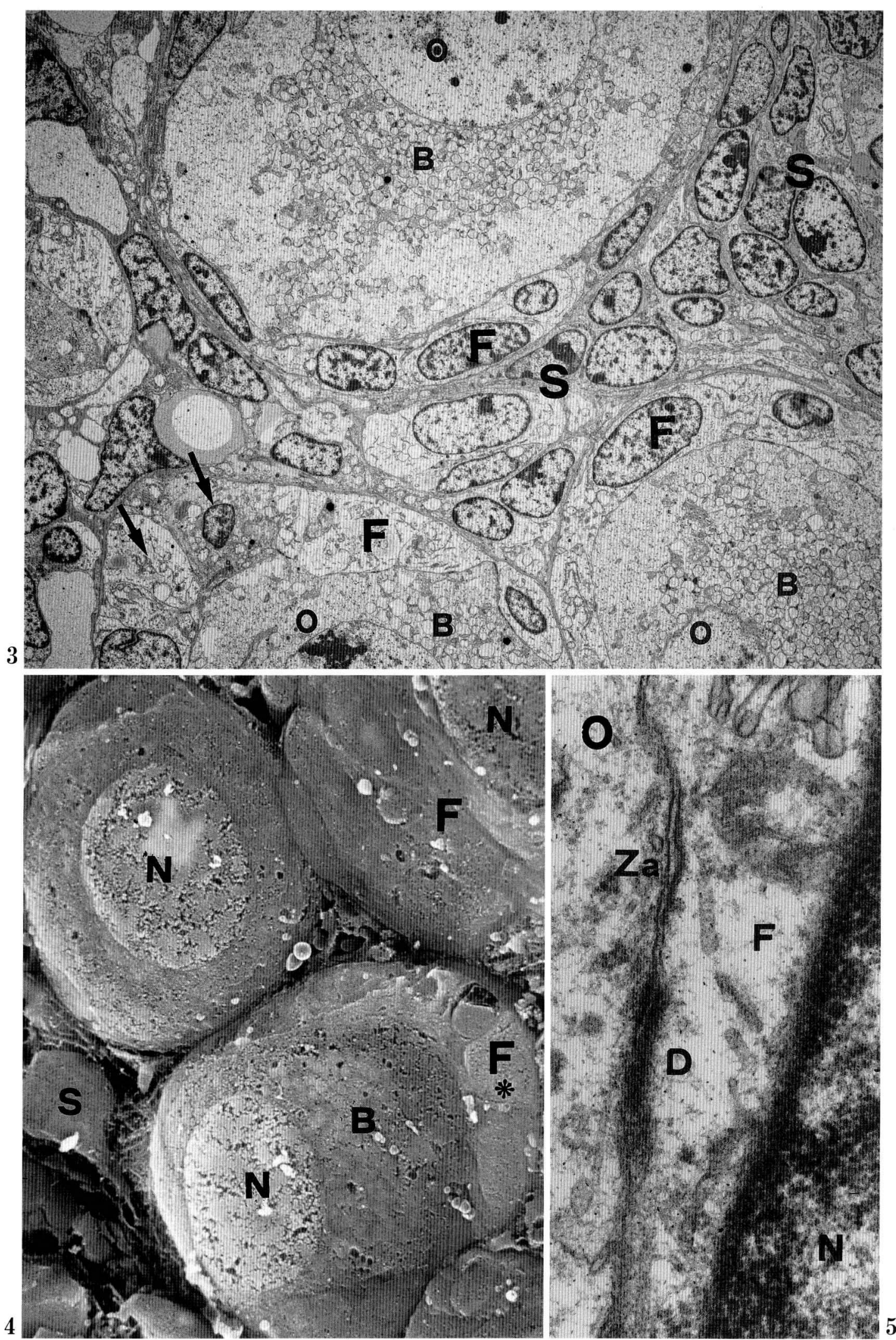

Figs. 3-5. Legends on the opposite page. 
(ZAmboni, 1971; Motta and Van Blerkom, 1975). At this time they begin to retract, thereby interrupting their contact with the oolemma (MotTA et al., 1992).

The major objective of this paper is to describe certain relevant structural changes which occur between the oocyte and associated follicular cells during follicle development in the human ovary, using high resolution scanning electron microscopy (SEM).

For this study in particular, we generally used the osmium-DMSO-osmium method (TANAKA and NAGURO, 1981) to great advantage. This method was recently adapted quite advantageously also to human biopsies including fetal tissues (MAKABE et al., 1992). In fact, this is one of the best maceration techniques since it is most effective in preserving the membranous cellular structures, while at the same time dissolving the cell matrix. This method permitted us to reveal, by high resolution SEM, fine 3-D details of the cell in a manner not previously available.

\section{MATERIALS AND METHODS}

Ten ovaries from 16-20-week-old human fetuses were collected following spontaneous and therapeutic abortions. Ovaries were also obtained during laparoscopy or abdominal surgery of 8 adult women aged between 22-41 years. A further two ovaries that were taken from an anaencephalic fetus at the time of delivery ( 38 weeks) were also used. All the specimens used in this study were obtained with the consent of each patient.

\section{Light, transmission and scanning electron microscopy}

Fragments of the fetal and adult ovaries were fixed by immersion in 2,5 glutaraldehyde in $0.18 \mathrm{M}$ sodium cacodylate at $\mathrm{pH}$ 7.3. After a few hours of immersion they were postfixed in $1 \%$ osmium tetroxide in the same buffer for 1-2 $\mathrm{h}$. They were then dehydrated through a concentration of ethanol and embedded in Epon 812. Sections obtained with an LKB or PorterBlum MT 1 ultramicrotome, mounted on unsupported grids, were stained with uranyl acetate (WATSON, 1958) and lead citrate (REYNOLDS, 1963). Examination was by transmission electron microscopy (TEM) in either a Zeiss EM 9A or Philips EM400 electron microscope. For light microscopy (LM), $1 \mu \mathrm{m}$-thick sections were stained with toluidine blue and photographed with Zeiss Ultraphot II.

For scanning electron microscopy (SEM), specimens were fixed in the same solutions as used for TEM. Dehydration was carried out rapidly through graded concentrations of acetone followed by transfer to liquid $\mathrm{CO}_{2}$ for critical point drying. Dehydrated specimens were mounted on aluminum stubs using conductive silver paint, and coated with gold-palladium by sputtering. They were observed and photographed using either a Cambridge Stereoscan 150 or Jeol 50 SEM.

\section{High-resolution scanning electron microscopy following the osmium-DMSO-osmium maceration (ODO) method}

The large ovarian specimens were immersion fixed in $2.5 \%$ glutaraldehyde for a few days and post-fixed in $1 \%$ osmium tetroxide in $\mathrm{M} / 15$ posphate buffer for 12 h.

After fixation, the specimens were rinsed with the buffer solution and were successively immersed in $15 \%, 30 \%$ and $50 \%$ aqueous solutions of dimethyl sulfoxide (DMSO) for $30 \mathrm{~min}$ each in order to prevent ice-crystal damage resulting from freezing occurring during the next step.

Specimens were frozen on metal plates chilled with liquid nitrogen, cracked into two parts with a razor blade and hammer, and were immediately placed in a

Fig. 3. Three primordial follicles are evident in the cortical stroma $(S)$ of an 18-week fetal human ovary. These follicles possess flattened follicular cells $(F)$ surrounding the large oocytes $(O)$. In one of these the flattened cells are enlarged, assuming a polyhedral shape (arrows). This type of follicle corresponds to an early "intermediary follicular stage". All the oocytes show typical paranuclear aggregations of mitochondria and membranes of the Golgi complex and endoplasmic reticulum (Balbiani bodies) $(B)$. (Compare these follicles by TEM with those by parallel TEM and SEM in Figs. 1, 2 and 4) TEM; $\times 2,500$

Fig. 4. Three quiescent primordial follicles similar to those of Figure 3 are evident in the ovary of an 18 -week human fetus. One of them shows a large "Balbiani body" $(B)$ and flattened follicular cells $(F)$ transforming into polyhedral cells (asterisk). This type corresponds to an early "intermediary follicle". $N$ nucleus, $S$ stroma cells. SEM; $\times 2,000$

Fig. 5. High magnification of the close apposition of the plasmalemma of a follicle cell and the oolemma in a primordial follicle of an 18-week fetal human ovary. This belongs to an area corresponding to one of those present in Figures 3 and 4. The plasma membranes form two "attachment zones": 1) a "zonula adherens" $(\mathrm{Za})$ and 2) a small desmosome ("macula adherens") $(D) . F$ follicle cell with its nucleus $(N), O$ oocyte. TEM; $\times 78,000$ 

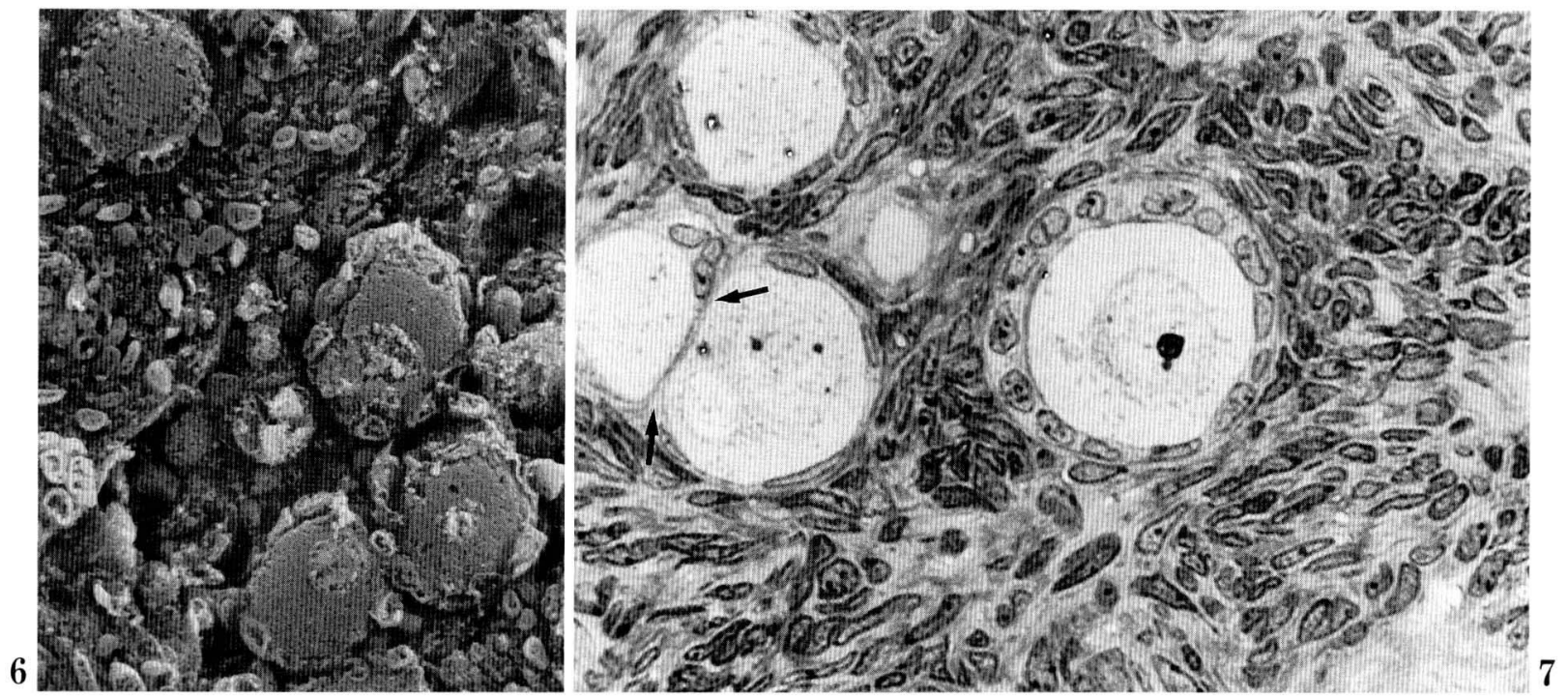

Fig. 6. Fetal human ovary at term (39 weeks). A typical nest of primordial and primary follicles included in the cortical stroma of the gonad is clearly seen. Many are the large oocytes and some are covered with various flattened and/or cubic follicle cells. SEM; $\times 900$

Fig. 7. Cortical stroma of an adult ovary (28 years old). There is a nest of three primordial follicles (on the left) and one "intermediary follicle" (on the right). The latter is at a stage between the primordial and primary follicle. The intermediary follicle shows both flattened cubic and polyhedral cells. Two primordial follicles (on the left) are closely associated and only a very thin layer of follicular cell cytoplasm is interposed between them (arrows). LM; $\times 450$

$50 \%$ DMSO aqueous solution.

After rinsing with the buffer solution, the specimens were immersed in $0.1 \%$ osmium tetroxide in a $\mathrm{M} / 15$ phosphate buffer at $20^{\circ} \mathrm{C}$ for $1-3$ days and then fixed again for $1 \mathrm{~h}$ in $1 \%$ osmium tetroxide in a $\mathrm{M} /$ 15 phosphate buffer.

The samples were conductively stained by immersion in a $2 \%$ tannic acid aqueous solution for $1 \mathrm{~h}$, and $1 \%$ osmium tetroxide in a $\mathrm{M} / 15$ phosphate buffer for $1 \mathrm{~h}$.

After dehydration in a graded ethanol series and treatment with isoamyl acetate, the specimens were critically-point dried and coated with about $3 \mathrm{~nm}$ of platinum in an ion coater equipped with a rotary tilt stage (VX-10R, Eiko Engineering Co., Ltd., Japan). They were observed with a field emission SEM (HFS2ST, Hitachi Co., Ltd., Japan).

\section{RESULTS}

Primordial follicles (about $50-70 \mu \mathrm{m}$ in diameter) arise in the human embryo from the sex cords and are present in the ovary from fetal life, progressively declining in number until the end of reproductive life (BAKER and Franchi, 1967; MotTA and MAKaBe, 1982; MAKABE et al., 1989). No differences were noted among these follicles at various life stages (MOTTA and VAN BLERKOM, 1980; FAMILIARI et al., 1989).

Since follicles are dynamic structures, those analyzed in this study were divided into 3 groups which roughly correspond to the principal stages of follicular development and oocyte maturation (DVORAK and Tesarik, 1980; BAKer, 1982): A) Primordial and primary follicles; B) growing preantral follicles; C) antral follicles. ${ }^{(*)}$

\footnotetext{
*Follicles of our Group A correspond to Stages 1 and 2; Group B: to Stages 3-6; Group C: to Stages 7-8 of the follicle classification proposed for mice by PEDERSEN and PETERs (1968) (see also BAKER, 1982). More exactly, the follicles examined in our study and included in the Group A correspond to the initiation and early stages of Class 1 follicles; Group B to Classes 1 and 2; Group C to Class 3 up to Class 4 of the classification specifically proposed for human ovarian follicles by GOUGEON (1990).
} 


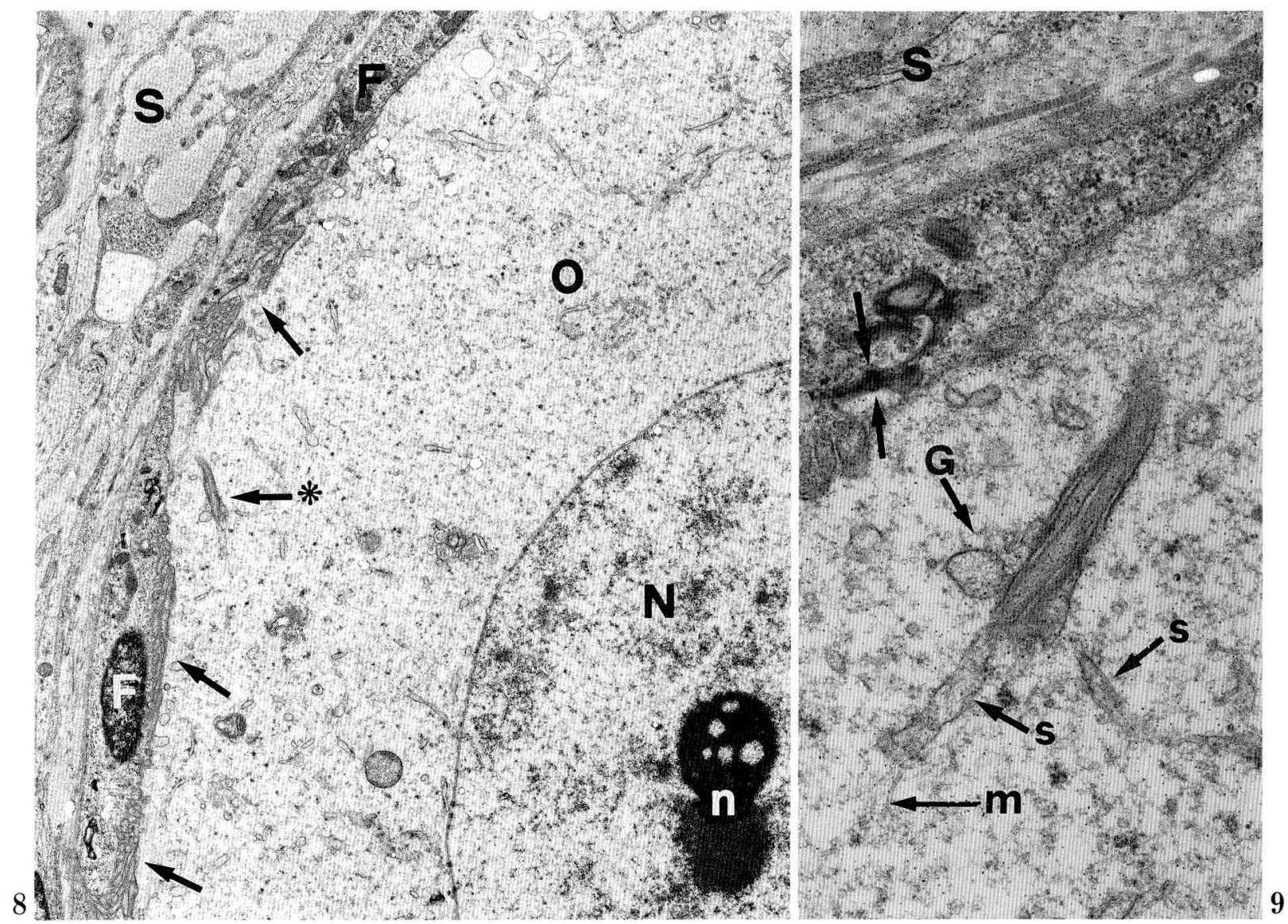

Fig. 8. Adult human ovary. A portion of a sectioned intermediary follicle (similar to that present on the right side of Figure 7) showing a large oocyte covered by a few flattened cells. The surfaces of the follicular cells $(F)$ facing the oocyte $(O)$ have a number of long and irregularly shaped microvilli closely squeezed on the oolemma (arrows). A microvillous projection appears invaginated in the cortical ooplasm (arrows plus asterisk). $N$ nucleus, $n$ nucleolus, $S$ stroma rich in cells and collagen fibers. TEM; $\times 4,300$

Fig. 9. High magnification of Figure 8 revealing in detail the intraoocytic microvillous invagination of the follicular cell. Membranes and vesicles of smooth endoplasmic reticulum ( $s$ plus arrows), Golgi vesicle ( $G$ plus arrow) and fragments of microtubules ( $m$ plus arrow) are closely associated with the intraooplasmic microvillus. Intercellular contact by means of microvilli and desmosomes (double arrow) is clearly evident between the oocyte and follicle cells. $S$ stroma. TEM; $\times 12,000$

\section{A) Primordial and primary follicles}

Primordial follicles are round structures consisting of a quiescent oocyte surrounded by a single layer of generally very flattened follicular cells. These are covered by a delicate basal lamina which serves to separate the follicle from the surrounding vascularized and innervated ovarian stroma.

At this stage, the oocyte shows a spherical or ovoidal shape (Figs. 1, 2). A large mass of cytoplasmic organelles consisting in a Golgi complex, membranes of endoplasmic reticulum, vacuoles, lipid droplets and stocks of annulate lamellae can be frequently seen close to the nucleus. They correspond to the so called "vitelline Balbiani body" (Figs. 1, 2). Most of its oolemma has a smooth surface and is closely apposed to the plasmalemma of surrounding follicular cells. Occasionally, narrow intercellular spaces may occur into which rare cytoplasmic extensions of both types of cells are projected (Figs. 2, 4).

In some areas between the oocyte and follicular cells, various types of cell attachments can be observed. Some are simply focal zones of increased opacity of the apposed plasma membranes, some correspond 

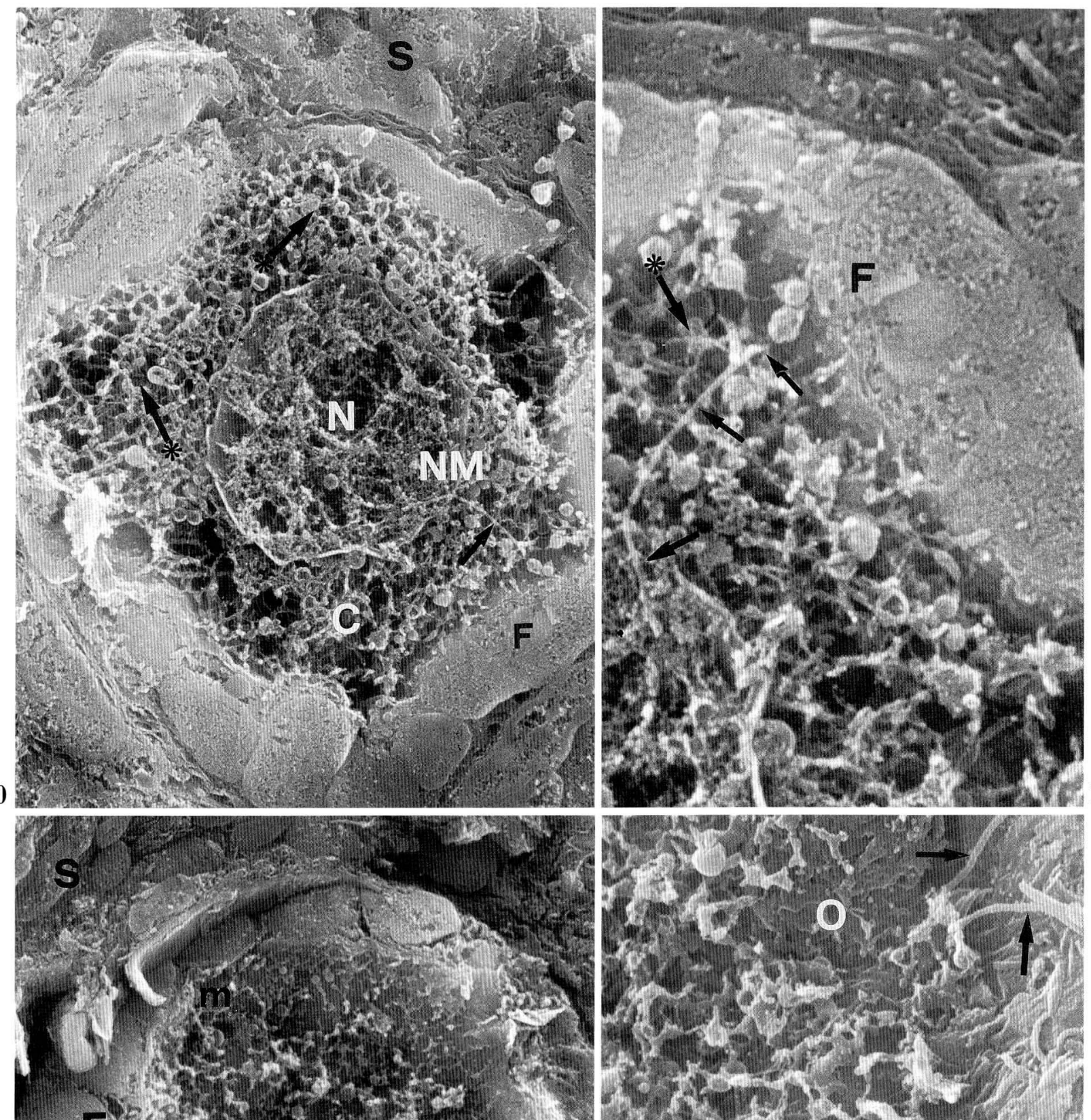

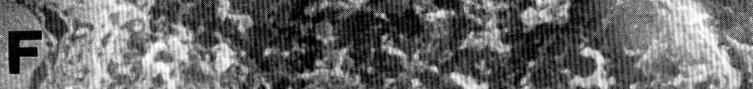

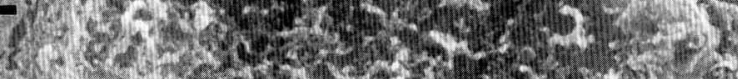

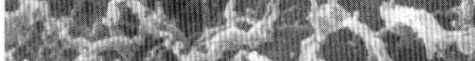

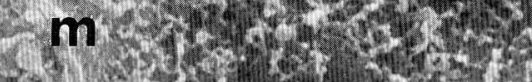

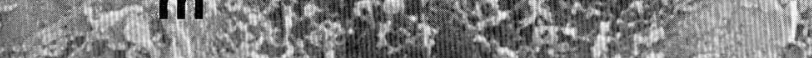
w.
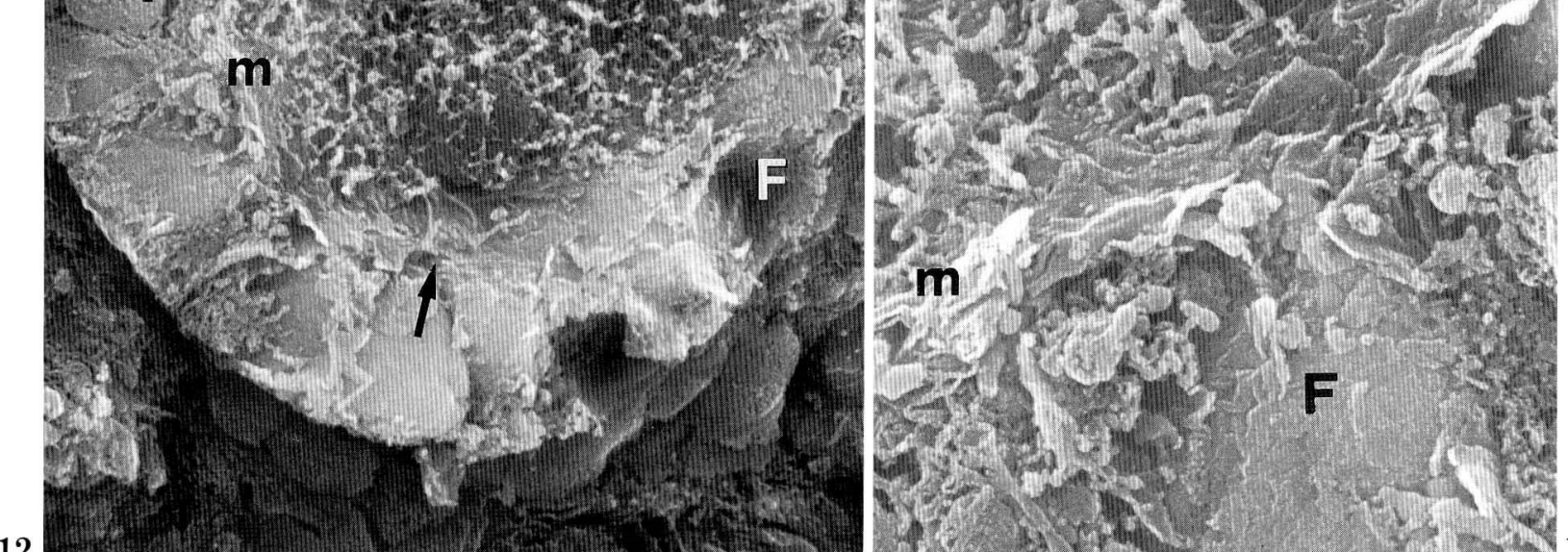

Figs. 10-13. Legends on the opposite page. 


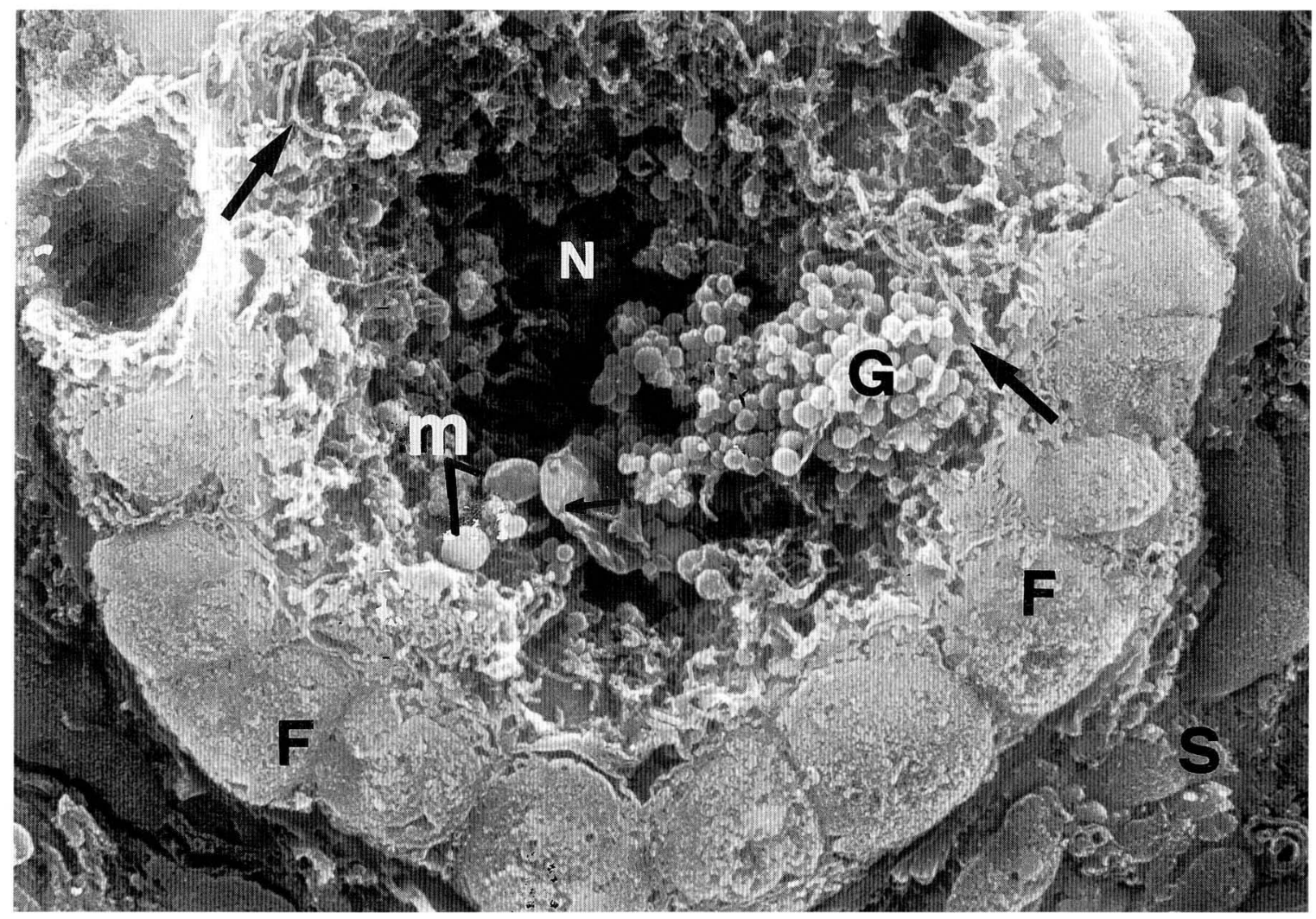

Fig. 14. Adult ovary. Developing primary follicle with cubic and polyhedral follicle cells $(F)$ closely apposed to a large oocyte. The partial maceration has dissolved completely the area occupied by the nucleus $(N)$ and most of the matrix of the oocyte. Within the cytoplasm there is a complex of lamellae and mostly vesicles corresponding to Golgi complex membranes $(G)$ and of endoplasmic reticulum. The larger spherical structures are mitochondria $(m)$. $S$ stroma. Intraoocytic microvilli from follicle cells can be also seen (arrows). SEM-ODO method; $\times 5,000$

Fig. 10. Adult human ovary. Fractured "intermediary follicle" showing a partially macerated nucleoplasm $(N)$ and cytoplasm $(C)$. From a cubic follicle cell $(F)$, there arises a long and thin microvillus (arrow). This runs deep into the oocyte and comes very close to the nuclear membrane $(N M)$. A thin microtubular net is present in some areas of the ooplasms interposed between various organelles (asterisk plus arrows). S stroma. SEM-ODO method; $\times 2,000$

Fig. 11. High magnification of Figure 10 already showing the long microvillous projection of the follicle cell $(F)$ into the ooplasm (arrows). Residual membranes and vesicles of the endoplasmic reticulum and Golgi are closely related to the intraoocytic microvillus. Residual microtubular structures are also evident (asterisk plus arrow). SEM-ODO method; $\times 6,200$

Fig. 12. Adult human ovary. Fractured primary follicle. The ooplasm has been well macerated following ODO treatment. Polyhedral follicle cell $(F)$ microvilli flattened against the residual oolemma are seen $(m)$. In one zone a few of these are invaginated into the cortical ooplasm (arrow). S stroma. SEM-ODO method; $\times 1,200$

Fig. 13. Adult human ovary. This is a detailed area of Figure 12 showing the microvilli $(m)$ of the follicle cells $(F)$ against the ooplasm $(O)$. Some of these closely penetrate its cortex (arrows). SEM-ODO method; $\times 5,200$ 
to the zonula adherens, and others to desmosomes. Finally, gap junctions can also be observed. Similar cell attachments have also been frequently observed between adjacent follicular cells and their microvillous extensions (Fig. 5).

Basically the features of primordial follicles correspond to those of the primary follicles. The main difference is that at this stage, intermingled with flattened follicular cells, others appear which increase in size and progressively proliferate, with some of these becoming cuboidal and polyhedral (intermediary follicle) (Figs. 4, 6, 7). The oocyte slowly begins to increase in size and is now surrounded by a greater number of flattened, cuboidal and polyhedral follicular cells (Figs. 7, 8, 10).

The intercellular spaces become gradually larger and cytoplasmic projections increase greatly in number and length. Those arising from the oocyte are few and irregularly distributed and occur either as very short isolated microvilli or as occasional slender microprojections. These are flattened against the surrounding follicular cells which are in close apposition to the oocyte (Fig. 8).

Concomitantly, most of the plasma membranes of follicular cells project numerous long and tortuous microvilli and larger extensions directly towards the

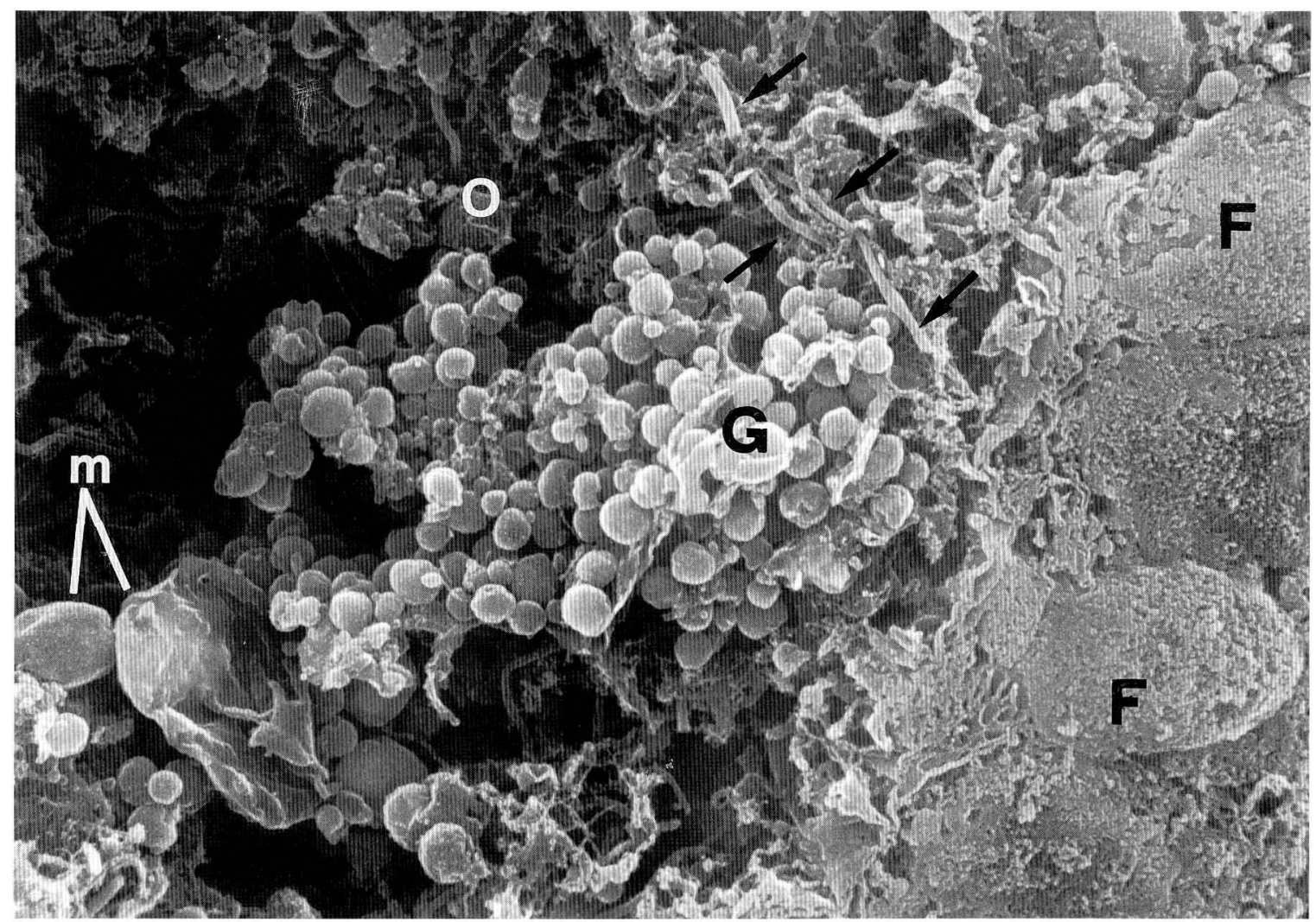

Fig. 15. Adult human ovary. This figure shows in great detail some of the long microvilli (arrows) arising from cubic follicle cells $(F)$ which project into the ooplasm $(O)$ of a growing primary follicle. The round organelles correspond to vesicles of the Golgi apparatus $(G)$ and endoplasmic reticulum. The larger spheroidal structures are small mitochondria $(m)$. The nucleus has been completely dissolved by ODO maceration technique. SEMODO method; $\times 20,000$

Figs. 16-18. Adult human ovary. In a primary growing follicle, intraoocytic microvilli are seen by high resolution SEM. In Fig. 16 a tortuous microvillus (arrows) arising from a follicle cell $(F)$ invaginates into the cortical cytoplasm. Fig. 17 depicts the continuation of the microvillus of Fig. $\mathbf{1 6}$ which runs very deep (arrows) within the ooplasm close to the nuclear zone $(N Z)$. Fig. 18 is a high magnification showing three microvilli (arrows) projecting deep into the oocyte. In all the figures the membranes surrounding the microvilli belong to Golgi elements $(G)$, mitochondria $(m)$ and endoplasmic reticulum $(E R)$ from which arise small blebs (arrow plus $B)$. The fine delicate network around the organelles is composed of residual microtubules (MT). SEM-ODO method; Fig. 16: $\times$ 20,000, Fig. 17: $\times 15,000$, Fig. 18: $\times 21,000$ 


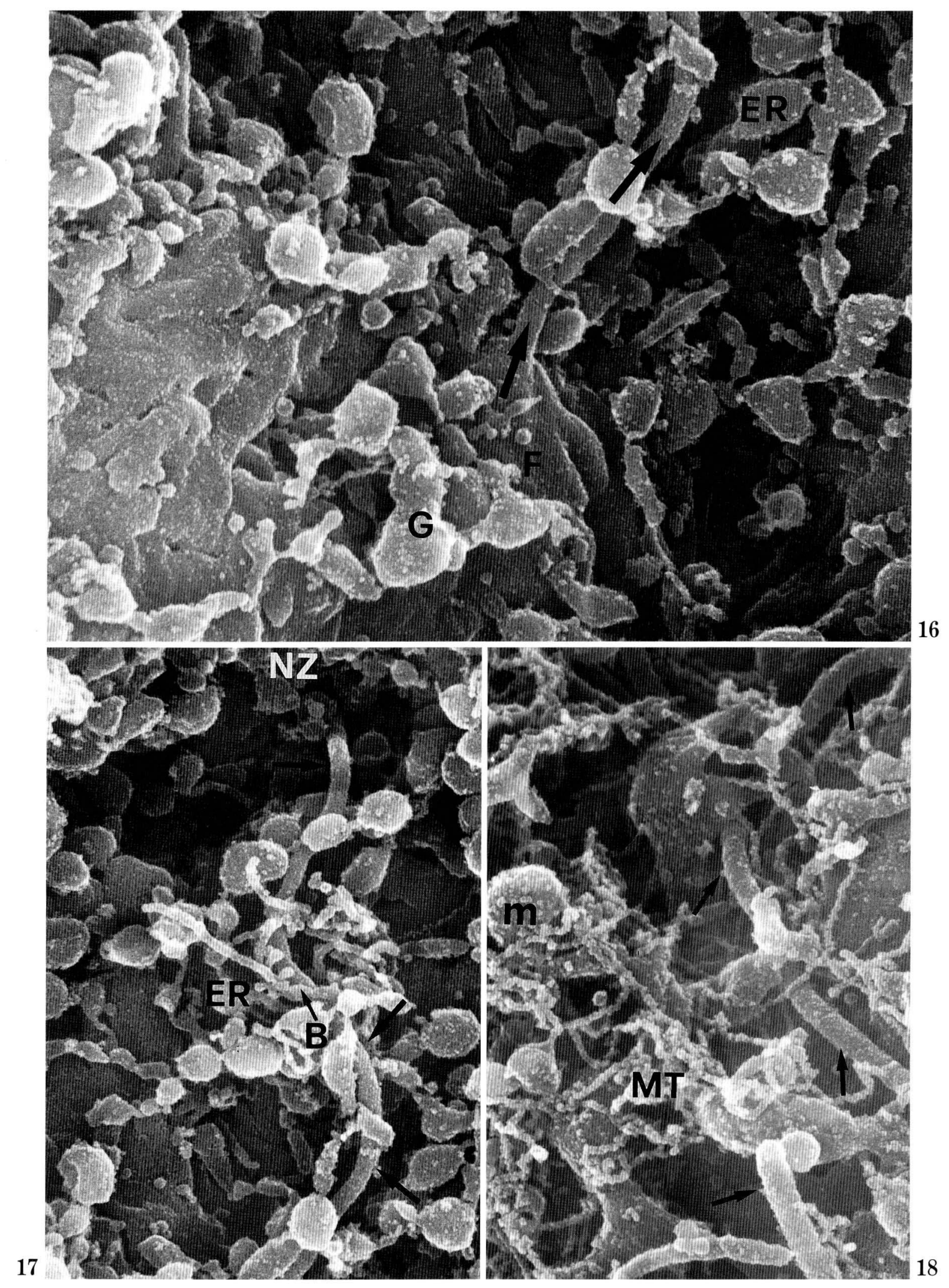

Figs. 16-18. Legends on the opposite page. 
oocyte (Figs. 8-10). Some of these appear extremely long and ramified in dendrite-like fashion. In such cases, they irregularly overlap and interdigitate with one another, thereby filling all the intercellular spaces present along the apical and lateral borders of the follicular cells as well as the narrow spaces around the oolemma (Figs. 8-10). In some cases, follicular microvillar-sites are found in corresponding surface infoldings of the oolemma. Others appear more extensively invaginated, penetrating deeply into the oocyte (Figs. 8, 9). In follicles fractured and macerated following the ODO method, the nucleus of the oocyte is often removed from the preparation along with most of the cell matrix. Thus, a favorable and complete view of the oocyte can be obtained (Figs. 10-15).

When the entire fractured ooplasm is analyzed by SEM at high magnification, it reveals numerous organelles, such as mitochondria, Golgi complex vesicles and lamellae and membranes of endoplasmic reticulum with closely associated small vesicles (Figs. 14-18). A number of microtubules can be seen among these organells in the ooplasm and microvillous invaginations (Figs. 9, 10, 11, 16, 18). In particular, long tubular projections are easily noted in full extension within the ooplasm. These probably correspond to the microvillous projections (Figs. 11, 13, 15, 16-19) which can also be seen in some parallel results by TEM (Figs. 8, 9).

These microvilli penetrate the oocyte, clearly appearing to arise from surrounding follicular cells (Figs. 10, 11, 14, 16). They may run deep within the ooplasm where they are closely associated with various membranous and vesicular fine structures which most probably correspond to Golgi elements and endoplasmic reticulum (Figs. 14-18). In some cases, these intraooplasmic microvillous projections are very long and take tortuous courses (Figs. 16-18). They are often either surrounded or masked by the above cell organelles, terminating near the nuclear zone (Figs. 10, 15, 17). Furthemore, they are occasionally associated with microtubules or with delicate tubular membranes from which apparently arise small buds and vesicles (Figs. 17, 18). These structures probably correspond to gently proliferating smooth endoplasmic reticulum membranes.

\section{B) Growing preantral follicles}

These follicles are characterized by frequent mitosis which results in an greater number of follicular cells that become arranged in an increasing number of stratified concentric layers around the oocyte. The follicle cells thus form the granulosa layer (stratum granulosum).

Small lacunae arise among granulosa cells which become filled with a dense secretory fluid called the "first" liquor folliculi. This is mostly secreted by follicle/granulosa cells. Further irregular and small masses of flocculent material are gradually deposited around the oolemma. These will fuse later and constitute a continuous and uniform thin layer, the zona pellucida, separating the oocyte from the surrounding follicular cells.

The follicular cell projections towards the oocyte in early growing follicles are now more numerous, tortuous and often consist of many slender ramifications. Similar to other areas, they form attachment zones in corresponding small infoldings of the oolemma. Follicular cell microvilli deeply invaginated within the oocyte can seldom be observed by TEM except in rather fortuitous sections (Figs. 19, 22). In parallel SEM observations on fractured specimens, following the ODO method, long microvilli are more easily found within the ooplasm. Here, as noted in earlier follicles, they may be surrounded or masked by oocyte organelles such as Golgi and endoplasmic reticulum membranes and mitochondria to which are also mixed irregularly shaped microtubules (Figs. 20, 21, Inset).

Fig. 19. and Inset. Adult human ovary. In this section there is a larger growing (preantral) follicle of a human adult ovary. Numerous cubic and polyhedric follicle cells $(F)$ tend to form many layers surrounding the oocyte $(O)$ where only a few organelles are seen. The closly apposed areas of the oolemma and follicle cells are rich in long and tortuous microvilli. Here "attachement zones" can be seen (arrows). Three microvillous invaginations projecting from adjacent follicle cells into the oocyte are also evident $(1,2,3$ plus arrows). The inset shows at high magnification follicle cells microvilli $(m)$; a desmosome (arrow plus $D$ ) between the oocyte $(O)$ and follicle cell $(F)$ membranes and a crossing section on an intraoocytic microvillus (arrow) are also evident. TEM; $\times 4,000$, inset: $\times 14,000$

Fig. 20. Adult human ovary. Growing preantral follicle in a stage similar to that of Figure 19. Note the cubic follicle cells $(F)$, that in some areas are already distributed into two proliferating layers $(*)$ surrounding the oocyte. It is likely that the plane of fracture of the specimen was at the level of the apical portion of an ovoidal follicle. Because the ooplasm was well macerated organelles and intracytoplasmic microvilli can be easily seen. $S$ stroma. Compare the parallel Fig. 19 and Fig. 20 by TEM and SEM. SEM-ODO method; $\times 2,500$ 


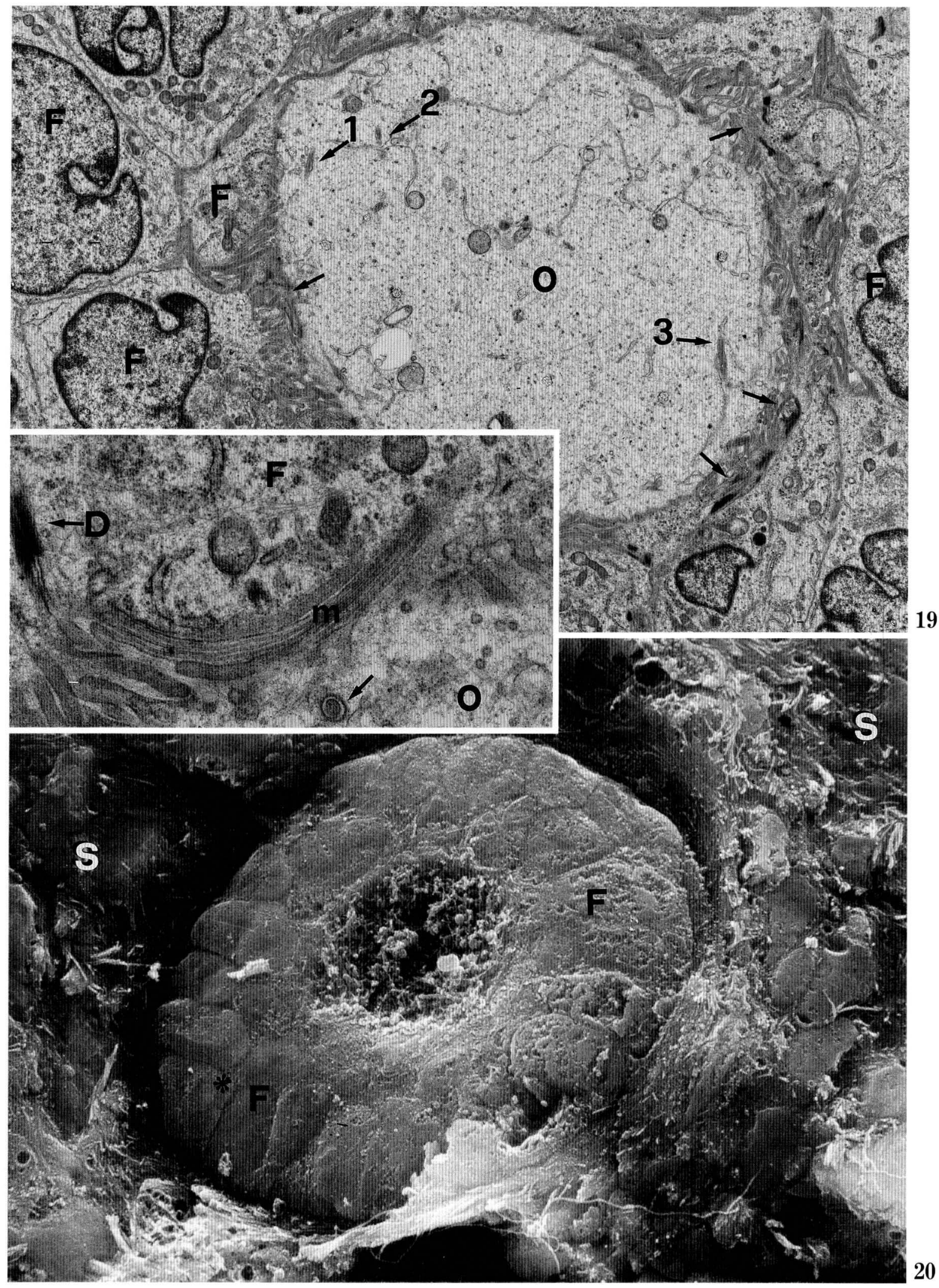

Figs. 19 and 20. Legends on the opposite page. 


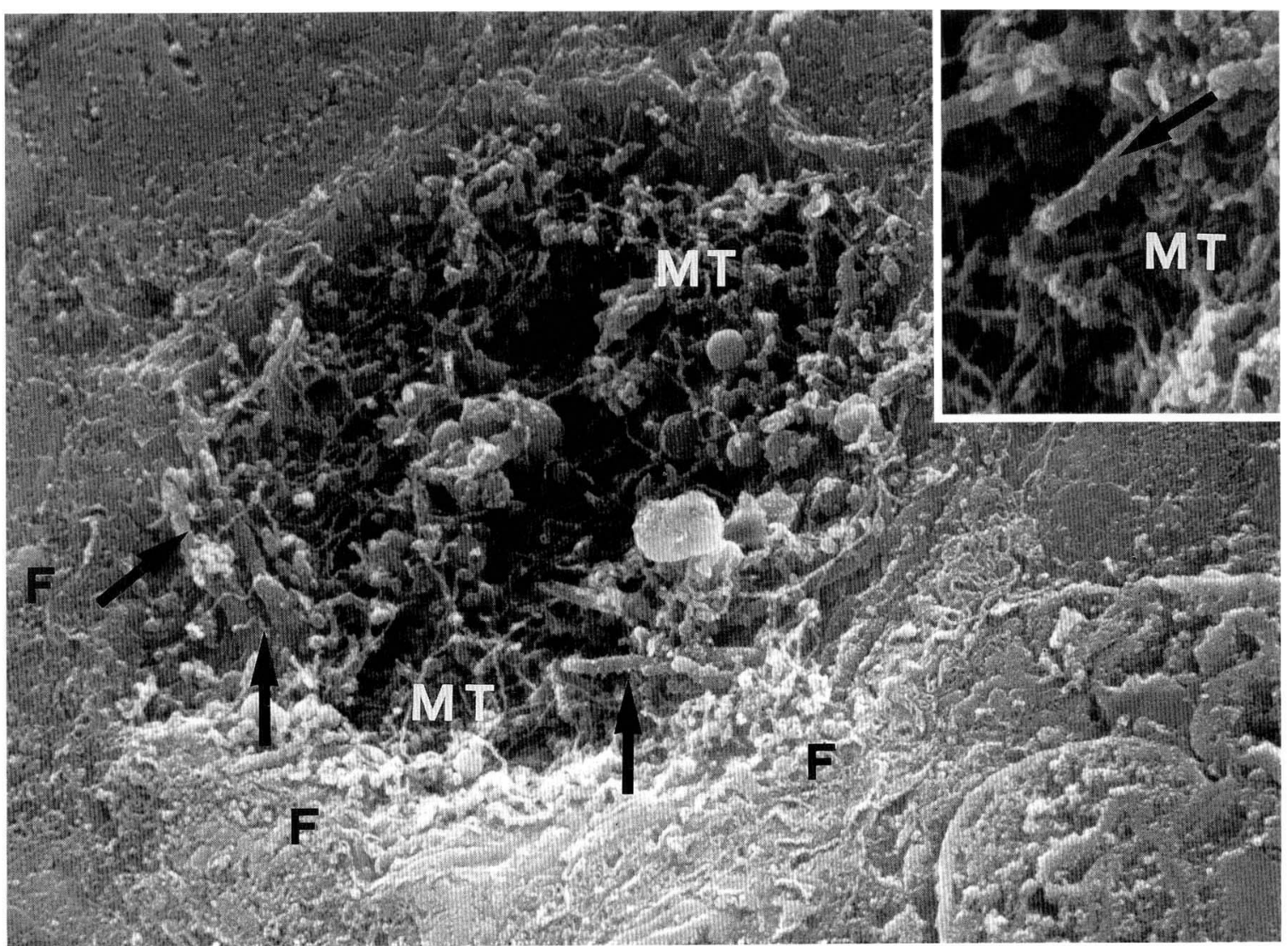

Fig. 21 and Inset. Growing preantral follicle of an adult human ovary. A detail of Figure 20, it shows at higher magnification microvilli (arrows) arising from adjacent follicle cells $(F)$ and running deep in the ooplasm. The fine network of filaments scattered within the ooplasm correspond to microtubules (MT). These aspects are more detailed in the Inset. SEM-ODO method; $\times 5,000$, inset: $\times 20,000$

\section{C) Antral follicles}

At this stage, the follicular fluid ("secondary" liquor folliculi) becomes gradually very abundant primary due to active transduction from the rich vascular supply of the thick thecal layer (MURAKAmi et al., 1988; MACCHIARELLI et al., 1991). This fluid progressively fills the intercellular spaces, creating large lacunae whose confluence finally gives rise to a single large cavity (antrum folliculi), with consequent peripheral dislocation of the oocyte and surrounding follicular cells (cumulus oophorus) (Figs. 23, 24).

The oocyte, which is now covered by a thick and dense zona pellucida, is apparently separated from the cumulus mass of follicular cells. Nevertheless, also at this stage, the innermost layer of surrounding cells (corona radiata) adhere to the outer surface of the zona pellucida through which they still project a number of long and irregular cytoplasmic processes which end over the oolemma (Fig. 24). Attachment zones between follicular cell projections and oolemma can also be observed at these stages, and consist of zonulae adherentes, desmosomes and gap junctions or simply small focal spots of increased opacities.

In routine ODO treated specimens, the zona pellucida of macerated follicles is not removed and appears as a dense layer. Thus, its structure does not differ much from that obtained in sectioned specimens (Fig. 24). On the other hand, the same ODO preparations can simultaneously offer a complete visualization of the oocyte, including microvillous projections of follicular cells due to the macerated and fractured oocyte matrix. Finally, when the specimens are subjected to the ODO maceration for a longer time (up to 3 days), the matrix of the zona pellucida can be gradually dissolved and the oocyte and follicular cell surfaces are exposed, thus revealing fine details. Therefore, taking advantage of the different ODO preparations mentioned above makes it possible to acquire important additional information on these cells. As a result, numerous and long 


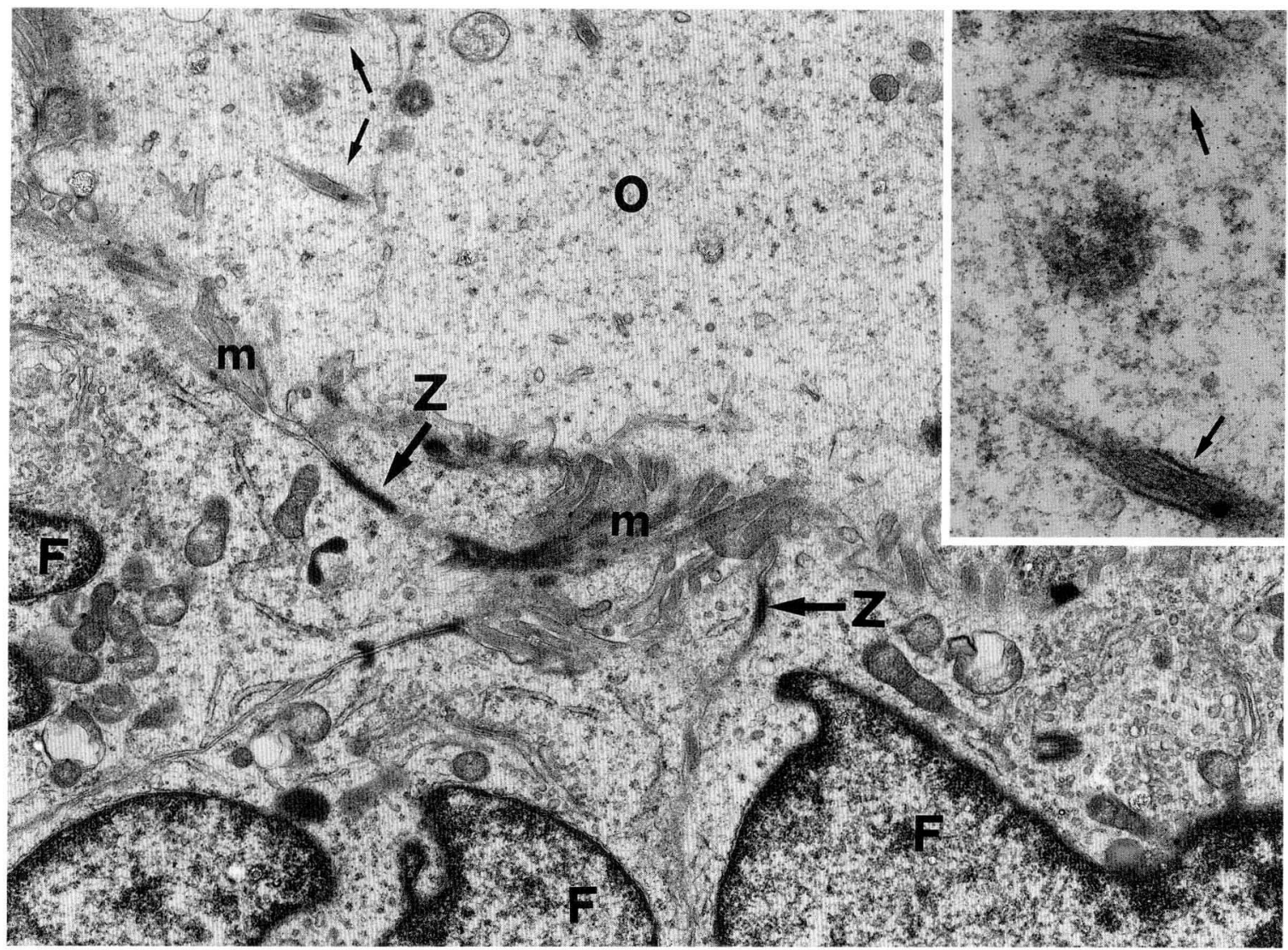

Fig. 22 and Inset. This is a detailed area of apposition between the oocyte $(O)$ and the surrounding follicle cells $(F)$. Numerous, long plicated microvilli $(m)$ are present. The two opposing membranes form numerous attachment zones ( $Z$ plus arrows). Two microvilli which are invaginated within the oocyte can be also seen (arrows). At higher magnification (Inset) they appear in full detail (Compare these figures with Fig. 21 and its Inset). TEM; $\times 7.500$, inset: $\times 20,000$

thin processes of follicular cells directed towards the oocyte or opening in the liquor folliculi of the follicular cavity are fully revealed (Figs. 25-27).

Many of these follicular cell projections reach the oocyte, making contact with its surface either perpendicularly or tangentially; a number of them are in close apposition to the oolemma.

The surfaces of the granulosa cells towards the antrum are also evaginated in a number of irregularly distributed long microvilli, small bulbous processes, and occasional short primary cilia (Figs. 23, 24, Insets) (MotTA, 1965; MotTA et al., 1971b). These structures are not only present on the free surface of the parietal granulosa layer towards the cavity, but also on the external granulosa cells composing the cumulus oophorus (Figs. 25-27).

Finally, when antral follicles are submitted to long ODO maceration periods ( $2-3$ days), the zona pellucida is completely dissolved, leaving the surface of the cells intact. As a result, oocytes may fall away from the fractured cumulus oophorus, so that the surrounding corona cells completely reveal the distribution and features of their cytoplasmic extensions (Figs. 25, 26, 28). In fresh specimens or in untreated preparations these cells are ordinarily masked by the sticky and dense zona pellucida.

The best preparations obtained by this method on antral follicles show corona cells closely associated with each other. They form portions of large spherical cavities where the oocyte covered by its zona pellucida was originally contained (Fig. 25). Corona cells are typically pear-shaped and their apexes, which are directed towards the oocyte, give rise to a large number of fine slender projections often concentrated to form a sort of plume. Generally these projections appear as long thin and curly microvilli (Fig. 28). Some of them are entwined, ramified and possess bulbous tips (Fig. 29). Together, they form an intricate and dense felt-like network. In other cases they appear as long and thin hair-like microvilli 


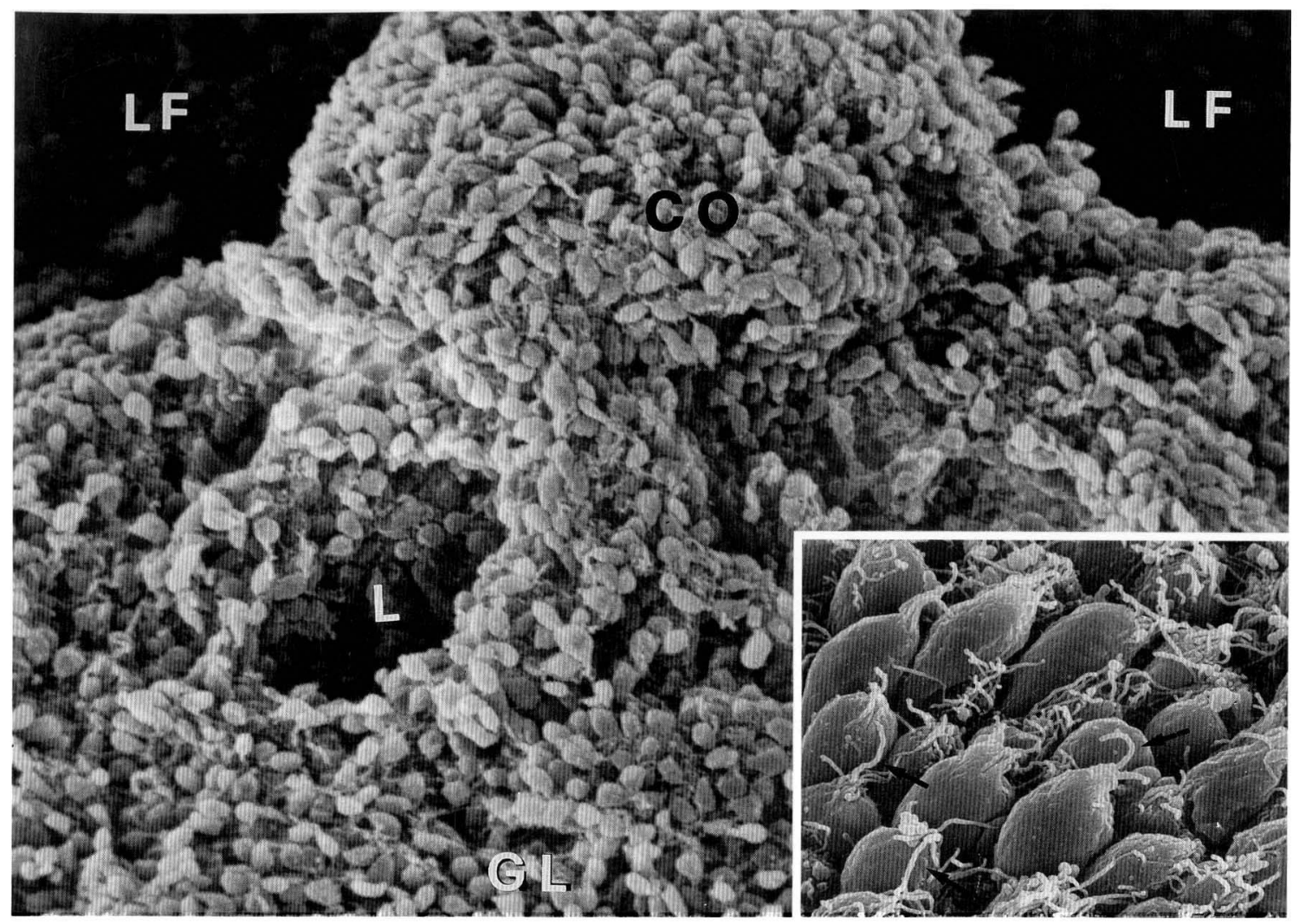

Fig. 23. Adult human ovary. Cumulus oophorus of a large antral follicle $(C O)$. Numerous follicle cells mask the oocyte which is covered by its zona pellucida. $L F$ residual liquor folliculi early filling the antrum and a small lacuna $(L)$ at the base of the cumulus. GL parietal granulosa layer. The Inset shows at higher magnification a group of cumulus cells. They are elongated in shape, have a smooth surface with a few microvilli and isolated cilia (arrows). These latter are rather thicker than adjacent microvilli. Compare these cilia by SEM with the cilium in the Inset of Fig. 24. SEM; $\times 300$, Inset: $\times 1,500$

sprouting from the apex of the cell (Fig. 28).

Seen by high resolution SEM following the ODO method, the cytoplasmic microvillous extensions of corona cells appear much more numerous than reported in other previous SEM and TEM studies (Figs. $28,29)$.

Intraoocytic follicular cell microvillous projections similar to those observed in early stages of growing preantral follicles were very rarely found in antral follicles (ZAMBONI, 1971).

\section{DISCUSSION}

When the oocyte starts to grow, in early developing follicles the flattened follicular cells become polyhedral and develop an increasing number of microvillous processes directed towards the oocyte. Some of these grow in apposition with the oocyte, their bulbous terminals coming into close contact with the oolem- ma, thereby forming the zonula adherens, desmosome and gap junctions. Many others, more similar to long microvilli, simply make contact with the oocyte (MOTTA et al., 1971a; ZAMBONI, 1971; VAN BLERKOM and Motta, 1979; Guraya, 1985; Sathananthan et al., 1986). Previous electron microscopic studies only occasionally revealed follicular cell extensions that penetrated deeply into the oocyte (ZAMBONI, 1971). Curiously enough, these structures, which are common features in amphibia (WARTENBERG, 1962; HoPE et al., 1963), were described incidentally in only two previous reports which specifically dealt with primates: the Rhesus monkey (HOPE, 1965) and man (BACA and ZAMBoni, 1967). To our knowledge, no other mammalian species studied thus far has shown such a follicular cell process which invaginates deep into the ooplasm. Our observations by high resolution SEM on selected fractured specimens subjected to the ODO maceration method are the first to fully reveal the topographical arrangement of these un- 


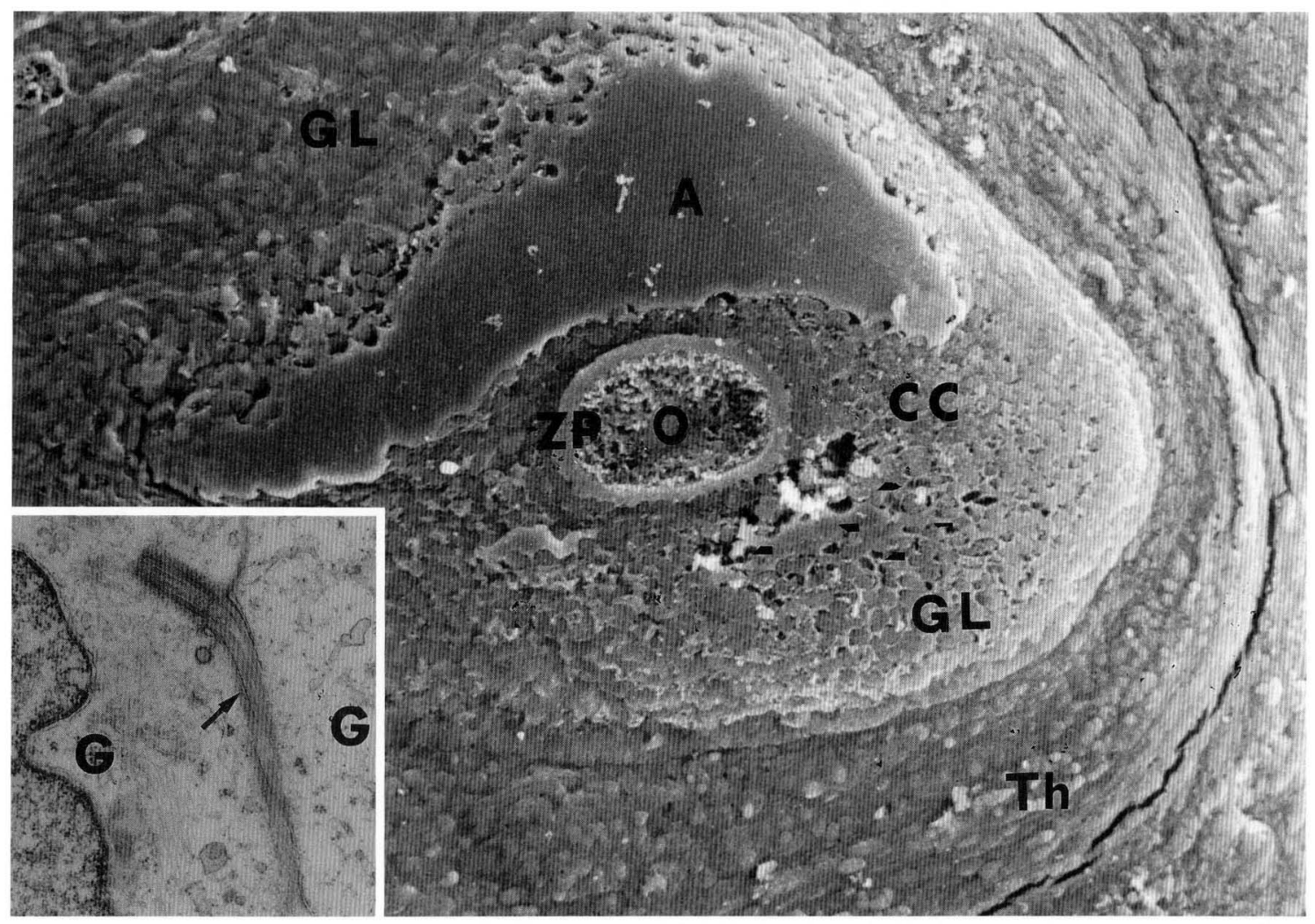

Fig. 24 and Inset. Fracture of an antral follicle of an adult human ovary. In this case the fracture shows the oocyte $(O)$ the zona pellucida $(Z P)$, the cumulus-corona cells $(C C)$ and the parietal granulosa layer $(G L)$. $A$ antrum filled with liquor folliculi, Th theca interna. The Inset shows at high magnification portions of granulosa cells $(G)$ polyhedral in shape located at the base of the cumulus oophorus. They possess a smooth surface, and from one of them an occasional isolated "primary cilium (arrow)" is projected in the narrow intercellular space. SEM; $\times 300$, Inset: $\times 6,500$

usual structures, thereby disclosing further details of great interest. In fact, when the fractured specimens incidentally contained the entire oocyte, more than one extension of this type was observed in the ooplasm. In some fortunate cases with only one plane of fracture, we even counted $3-5$ of them (Figs. 14, 19, 21 ). In addition, if the total volume of the oocyte and the actual number of its surrounding follicular cells are considered, these structures are certainly more numerous than those observed in a single fractured specimen. Therefore, it is logical to conclude that the presence of such "intracytoplasmic processes" can no longer be regarded as an occasional event (Fig. 30).

In many of our cases, these follicular projections were observed penetrating deep into the ooplasm, thus coming very close to the nuclear envelope. These results correlate well with the occasional but accurate observations of BACA and ZAMBONI (1967) on human oocytes. In their study, a projection penetrating deep into the oocyte was reported to termi- nate a few micra from the nucleus. It appeared as a long tubular invagination having a diameter similar to that of a microvillus and showing a very tortuous course.

Within the ooplasm-whose matrix was basically dissolved by the ODO method used in our studythese follicular projections were often in close association with a variety of organelles, such as endoplasmic reticulum membranes, Golgi vesicles and mitochondria. In some cases, a portion of their surface was characteristically surrounded by minute tubular membranes giving rise to delicate blebs.

According to their shape and size, these latter structures most likely correspond to a tubulo-vesicular form of a nascent smooth surface endoplasmic reticulum (FAWCETT, 1981). In our study, follicular cell extensions into the oocyte were found at initiation in early growing preantral follicles. These mostly consisted of follicles containing an oocyte which was surrounded by anywhere from one to four con- 


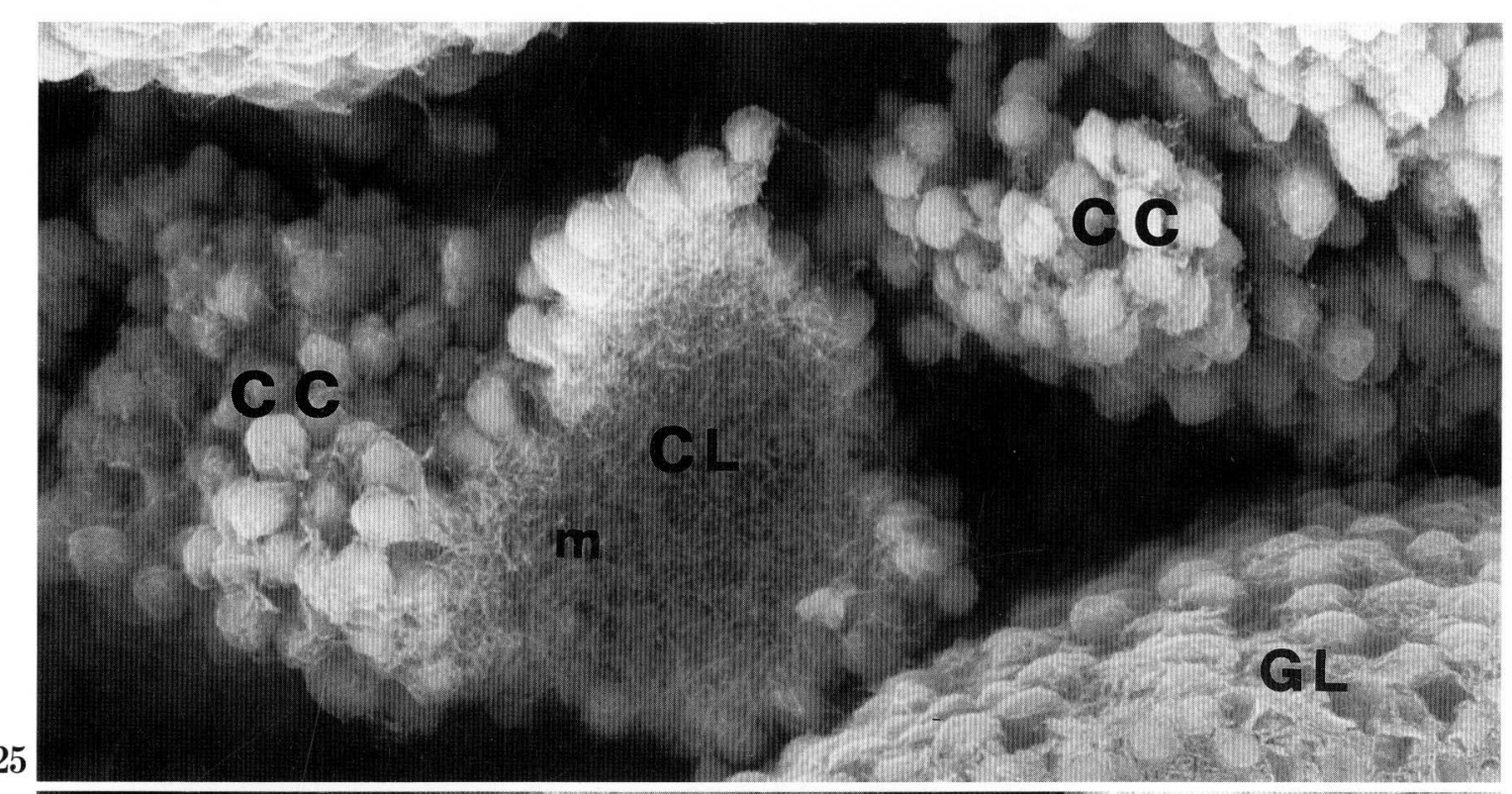

25

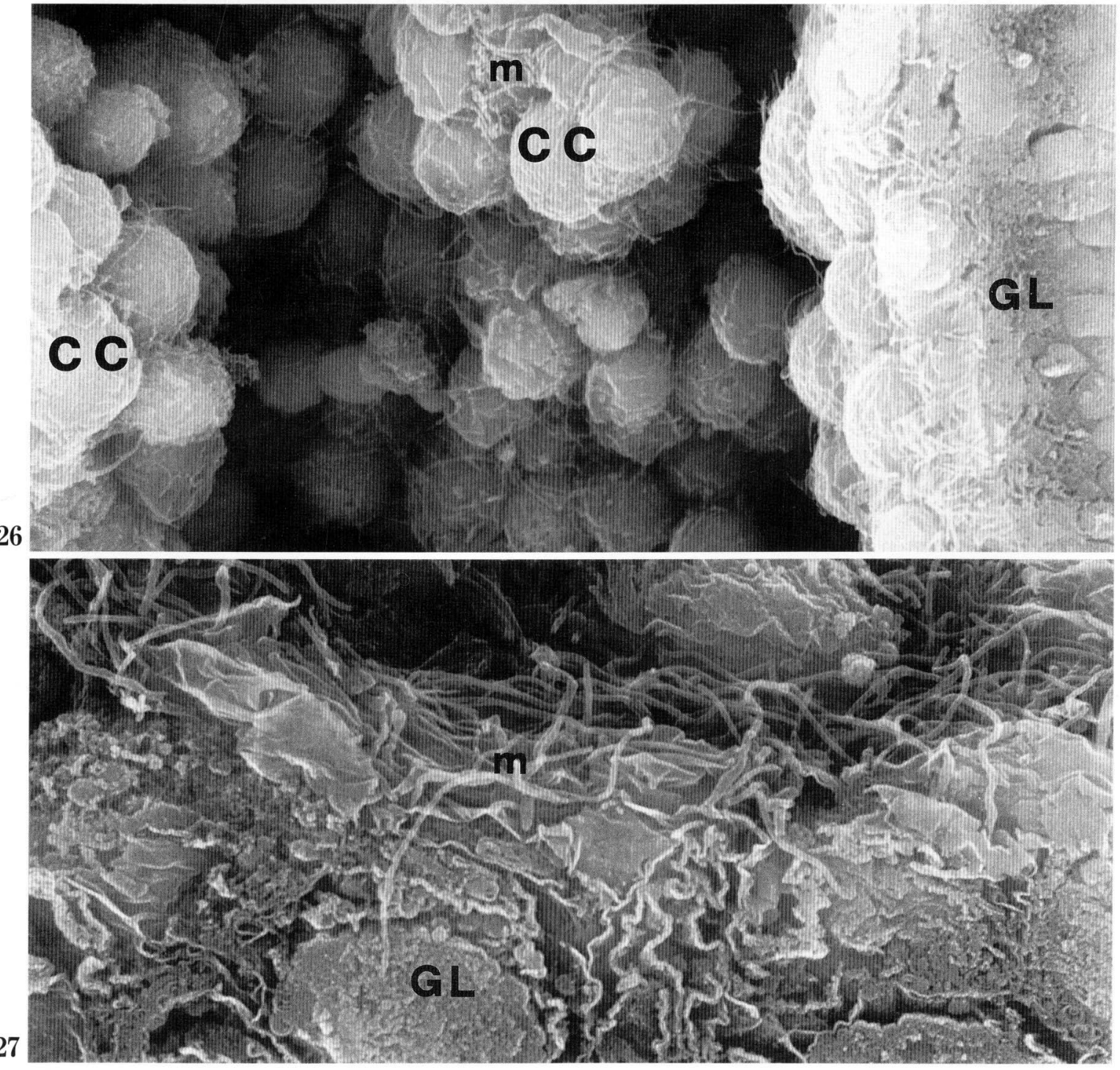

Figs. 25-27. Legends on the opposite page. 
centric layers of follicular cells. In these follicles the zona pellucida material was generally not yet formed or appeared as isolated and very small flocculent inclusions. The "intraoocytic" processes were, as a rule, projected from the innermost layer of follicular cells which were in direct apposition with the oolemma. In later stages of follicle development (large antral follicles) with a thick zona pellucida, intracytoplasmic extensions into the ooplasm were rarely observed, as was also confirmed by the very occasional report of BACA and ZAMBONI (1967).

The presence of such structures within the ooplasm in early developing follicles generally coincides with the great increase in volume of the oocyte. As a rule, oocyte activation is believed to depend upon the numerous contacts (especially gap junctions) that follicular cell membranes establish with the oolemma, as reported in all mammalian species observed thus far (LARSEN, et al., 1987). Nevertheless, the presence of these additional intraoocytic extensions, which apparently are seen only in primates (Rhesus monkey and man) (HOPE, 1965; BACA and ZAMBONI, 1967; ZAMBONI, 1971), suggests that a special intimate relationship between follicular cells and the oocyte is perhaps required for the oocyte to grow in these species. in fact, there is no doubt that long follicular processes, penetrating into the ooplasm through deep invaginations of the oolemma like a sword in its sheath, might transfer more extensively and easily a variety of ions or molecules-including nutrients-into the innermost areas of the oocyte. Furthermore, the frequent proximity of these intracytoplasmic processes to oocytic organelles does not exclude the fact that they do contribute to oocyte growth activation. This may in turn be mediated or integrated by parallel activation of specific oocyte organelles and their cohort of enzymes.

Therefore, it is tempting to suggest that such follicular extensions within human oocytes may be particularly involved in providing the early stimuli to the oocyte to grow or at least be involved in such a process. Naturally, the authors are aware that morphological evidence alone would not be sufficient to validate this hypothesis, since it is an accepted fact that signals and/or nutrients are transferred to the oocyte by means of numerous close follicular points of contact (MotTa et al., 1971a; AlberTini and
Anderson, 1974; GILUla, 1977; LARSEN et al., 1987).

On the other hand, it is an obvious inference that, if signals are able to move from follicular cells to the oocyte, they may travel in the opposite directions as well. In this way, a more efficient, synchronous coordination of timed developmental events may occur in the follicle-oocyte complex, which in a sense, operates as a kind of "functional syncytium" (MotTA et al., 1971a, b).

Once established, the close relationship between the oocyte and follicular cells is maintained in the following stages of follicle development as well. In later stages of growing follicles, when the oocytes were covered by a thick zona pellucida, no intraoocytic follicular processes were encountered. On the other hand, extremely numerous follicular extensions penetrated the zona and were directed towards the oocyte. Some of these, resembling long filopodia, came in contact with the oolemma after establishing various types of intercellular connections which most likely correspond to gap junctions, zonulae adherentes and desmosomes (ZAMBONI, 1971; MOTTA and VAN BleRKOM, 1979; SATHANANThan et al., 1986, 1993).

The particular modification of using a long ODO maceration method (up to 3 days) with consequent dissolution of the zona material. (MAKABE et al., 1992) was advantageous in fully revealing the true 3-D patterns of follicular cells and their extensions.

In these preparations, follicular cells (corona cells) which were originally apposed to the zona pellucida were typically pear-shaped and showed a marked polarity. In fact, they presented a smooth surface with the exception of the cellular pole which was directed towards the oocyte and from which the cytoplasmic processes originated. These processes appeared as extremely long and curly filiform extensions which spread tortuosly in various directions and intermingled with those arising from adjacent follicular cells. In general they resembled very long, unusual microvilli or more precisely epididymal stereocilia as seen in SEM studies (MURAKAMI et al., 1975). In addition, some of them were ramified and showed bulbous tips. As a rule these unusual microvilli measured 7-10 $\mu \mathrm{m}$ in length and the apical surface of a single corona follicular cell towards the oocyte

Figs. 25-27. Antral follicle of human adult ovary. Due to the long maceration by ODO method, the different components of the follicle are evident at various magnifications. The zona pellucida and liquor folliculi have been dissolved, leaving in place the cellular components. The coronal cell layer $(C L)$ with microvilli corresponds to the area where the oocyte and zona were previously located. Cumulus cells $(C C)$ and parietal granulosa cells $(G L)$ are also present. Note the different number and pattern of microvilli $(m)$ in the 3 different follicular areas shown in the pictures. SEM-ODO method; Fig. 25: $\times 550$, Fig. $26: \times 1,200$, Fig. $27: \times 3,000$ 


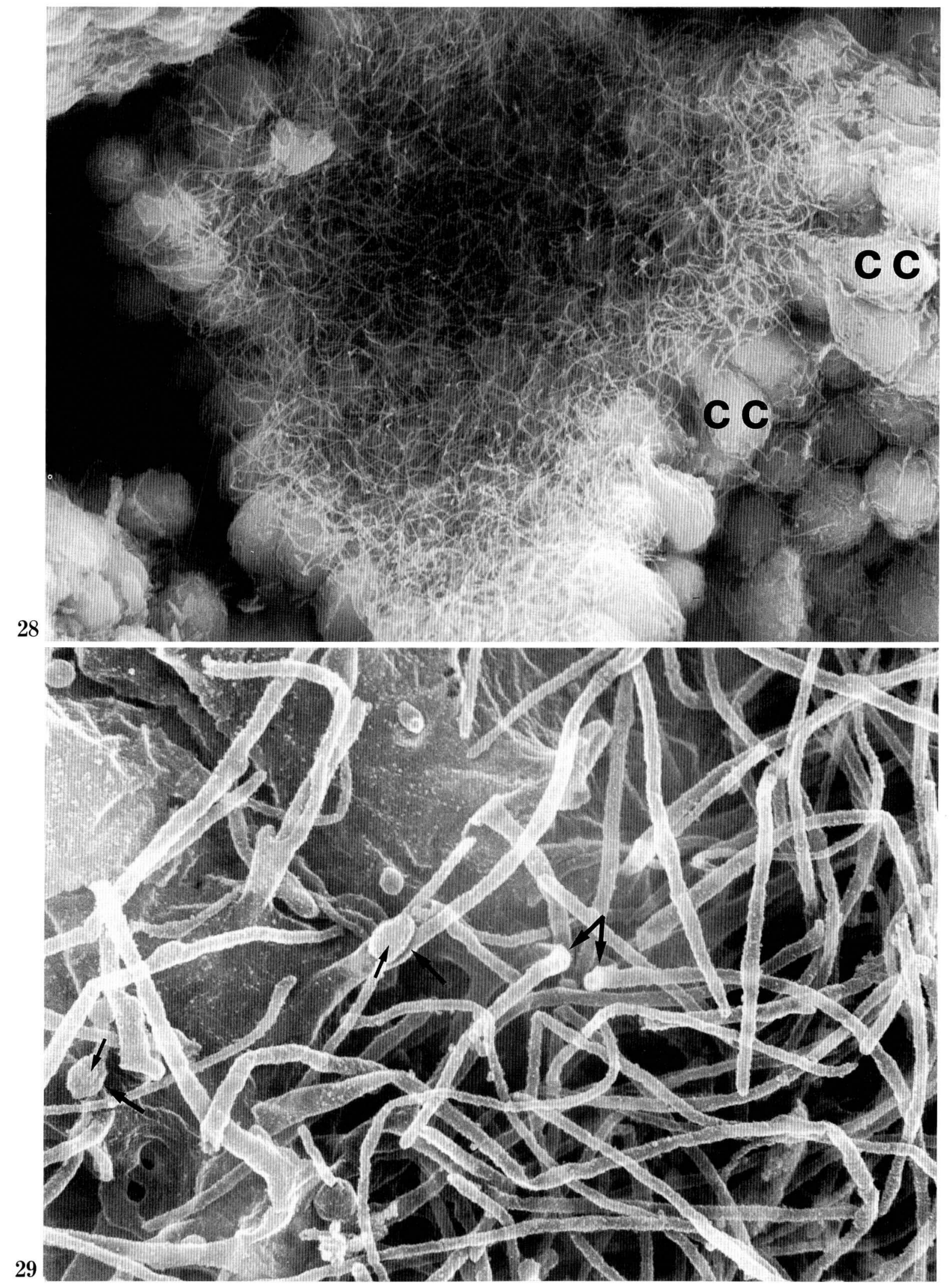

Figs. 28 and 29. Legends on the opposite page 


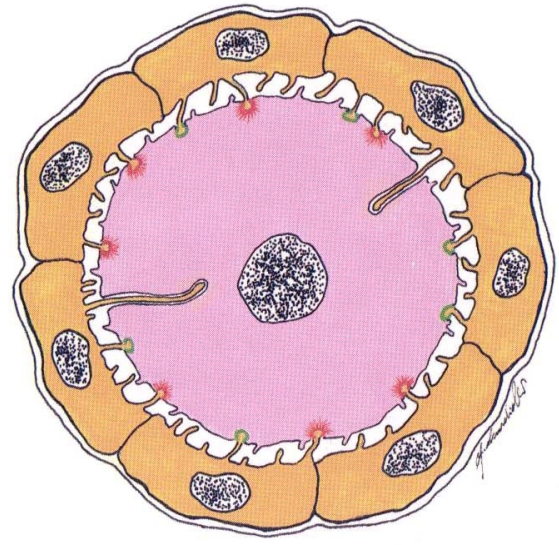

A

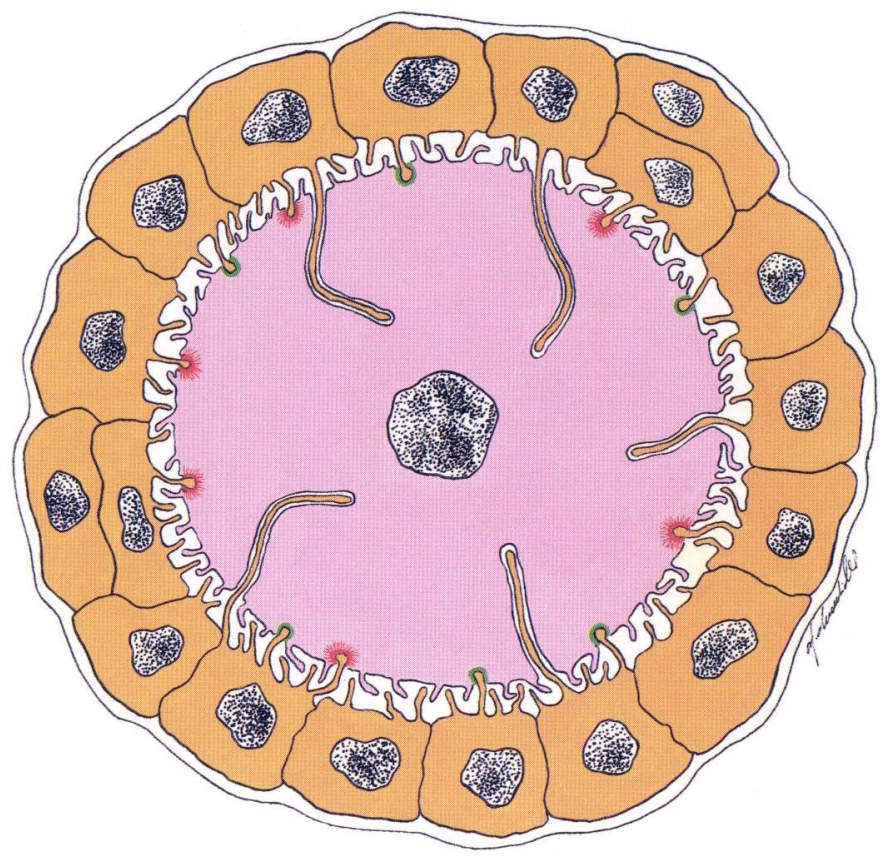

Fig. 30. This diagram depicts schematically two different stages (A and B) of a primary developing follicle with follicle cells in close contact with a growing oocyte. Early on, the follicle cells project a number of microvilli towards the oolemma which form various types of cellular contacts. These consist of: a) mechanical attachments such as "zonulas adherentes" and "desmosomes" (red marks) and b) communicating junctions such as "gap junctions" (green marks). In addition, some follicular microvilli invaginate deeply, penetrating the ooplasm and often coming close to the nuclear zone. These additional "intraooplasmic microvillous projections", which in vivo are probably very dynamic, may help to activate the oocyte to grow, coordinating the various functions of the oocyte follicle cells complex (see also the text).

Figs. 28 and 29. Antral follicle of human adult ovary. High resolution in Fig. 28 allows the details of the "microvillous apparatus" of corona cells layer to be seen. The abundant thin microvilli facing the oocyte form a formidable and continuous microvillous network. Note the typical pear-shape of many of the corona cells $(C C)$ whose apex has tufts of many long microvilli. Fig. 29. At higher magnification many of the long microvilli radiating from corona cells have a tortuous course and may end with a small bud at their tips (arrows). SEM-ODO method; Fig. 28: $\times 1,200$, Fig. 29: $\times 9,000$ 


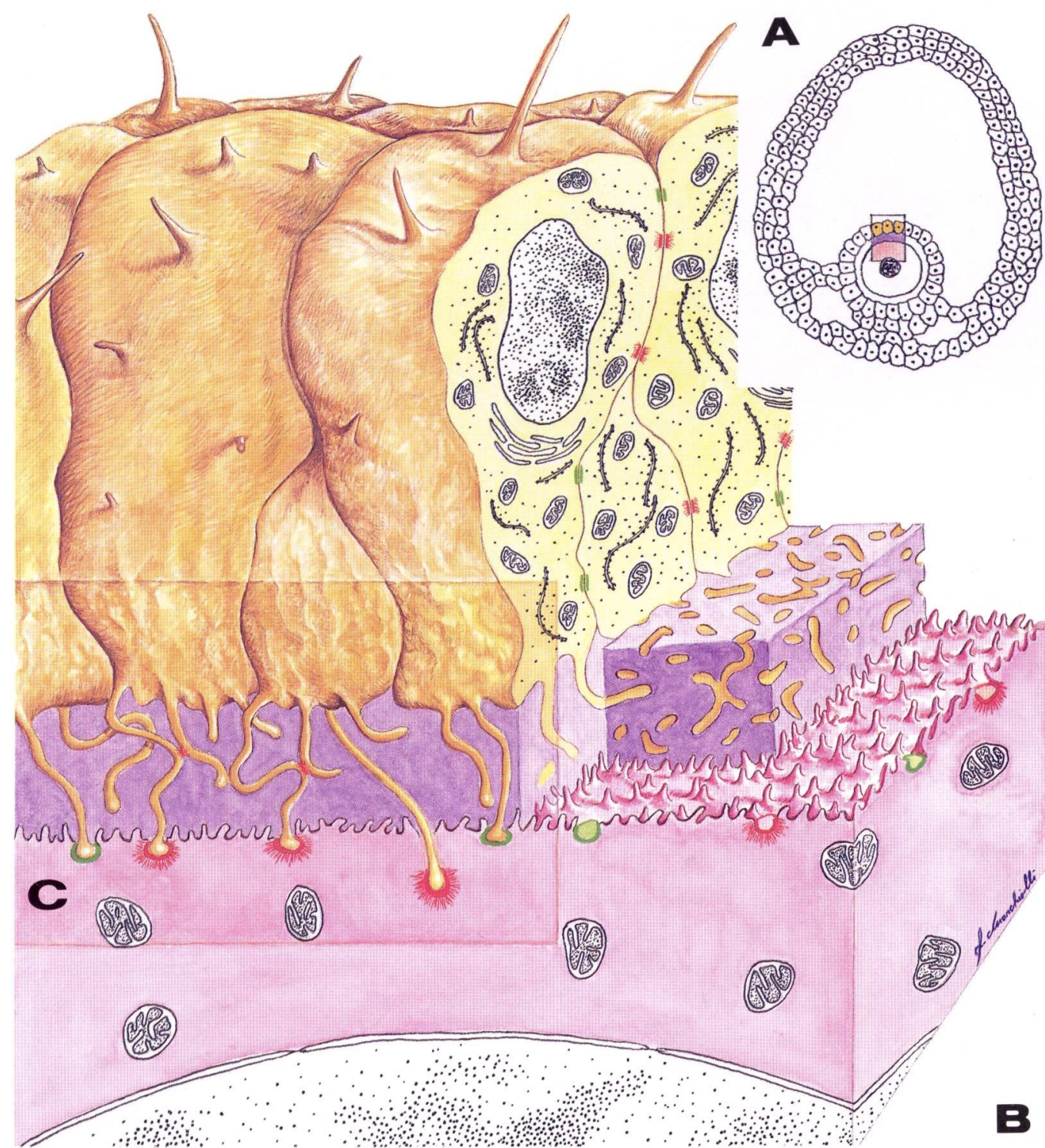

A Antral follicle

3 Detail of boxed area

C General view of the area detailed in $\mathrm{C} 1, \mathrm{C} 2$

$\square$

Cumulus corona cells

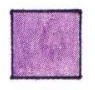

Zona pellucida

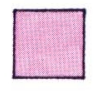

Oocyte

Mechanical junctions (desmosomes and zonulae adherentes)

(U) Gap junctions

Fig. 31. The various pictures $(\mathbf{A}, \mathbf{B}, \mathbf{C 1}, \mathbf{C} 2)$ illustrate in a 3-D manner the detailed relationship between corona cell projections and oolemma throughout the interposition of the zona pellucida. As in early developing follicles in antral follicles the cells around the oocyte (corona cells) form very numerous and long microvilli which are contained in the microlabyrintine microtunnels of the spongious zona pellucida. The results suggest that in the living state these follicular microvilli,, 

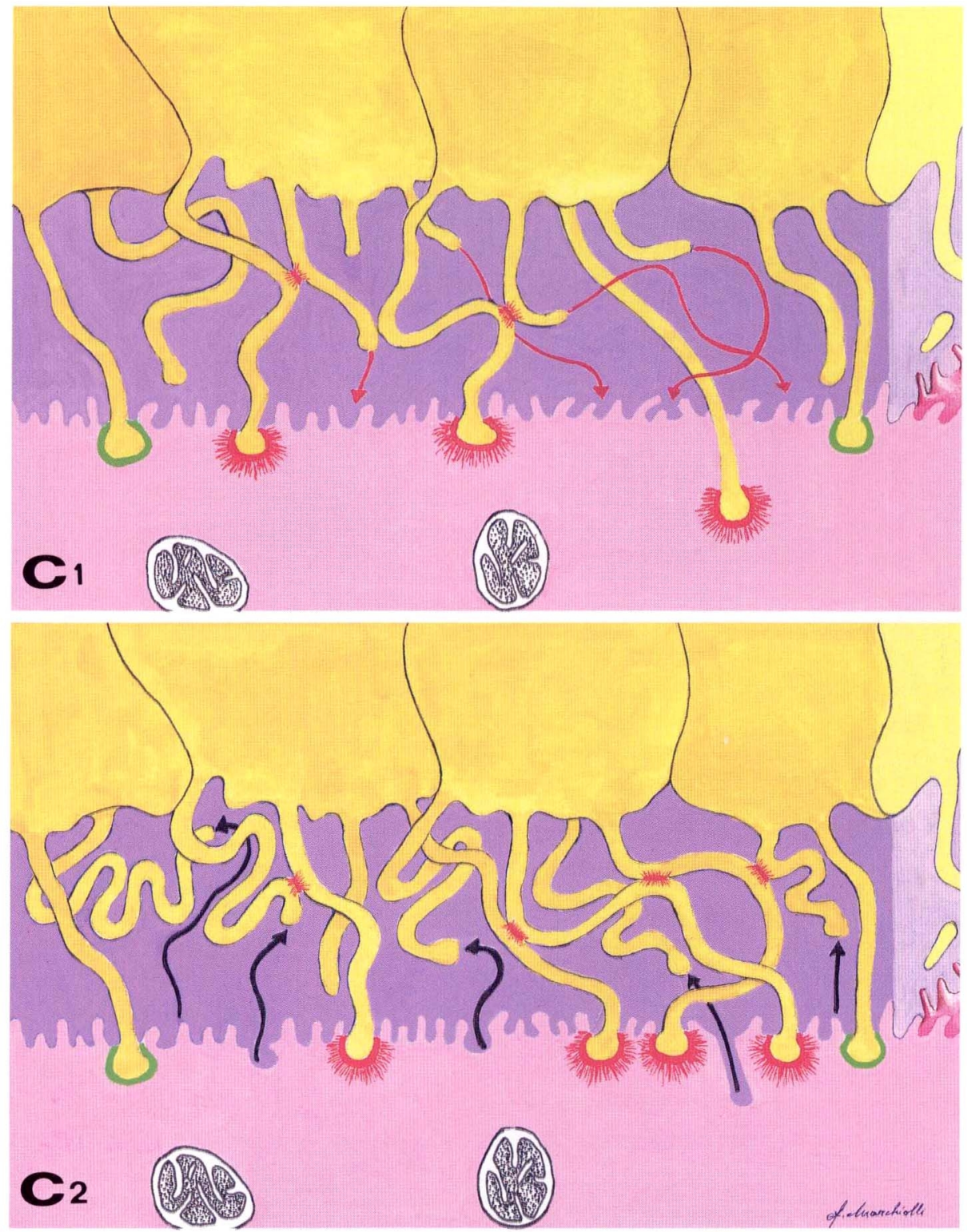

Mechanical junctions (desmosomes and zonulae adherentes)

contractile in nature, can move continuously and easily. Thus the microvilli, and their tips elongating or contracting, can form various dynamic plasmalemmal contacts with the oolemma. In particular, $\mathbf{C} 1$ and $\mathbf{C} 2$ represent in a dynamic manner (arrows) two sequential stages of an area of cumulus corona cell-zona pellucida-oocyte contact and of their related movements (for further details see the text). 
could form up to 70 long microvilli (MAKABE et al., 1992). Similar extensions were only rarely observed over the remaining surfaces of the corona cells facing the antrum, and not over the surface of associated cumulus and parietal follicular cells.

In preovulatoty follicles, some parietal granulosa cells, most likely undergoing luteinization, showed a certain number of similar thin microvilli. In these cases, it has been suggested that they may serve to increase the surface area of granulosa cells which are under hormonal control. In turn these enlarged plasmalemmal areas may be consistently used as binding sites for increasing quantities of gonadotropins (MOTTA and MAKABE, 1981; AMSTERDAM and ROTMENSCH, 1987).

Finally, many granulosa cells of preantral and antral follicles revealed a single primary cilium. The occurrence of such an organelle common to many mammalian species may represent a rudimentary organelle or may have a chemoreceptive role (MOTTA, 1965; MOTTA et al., 1971b; VAN BLERKOM and MOTTA, 1979; SATHANANTHAN et al., 1986).

As revealed by SEM, the cytoplasmic processes of corona cells with their tortuous course and their extensive intermingling with each other contribute to form a characteristic microvillous network. Anchored as bridges to the oocyte surface, they provide a sort of cytoplasmic skeleton supporting the zona pellucida. As suggested by their 3-D organization, additional functions of these structures may be: 1) transport of substances to build up the zona pellucida; 2) release of nutrients into the zona, which in turn are absorbed by the oocyte; and 3) removal of material (catabolites) from the zona as well as from the oocyte.

In this way, the zona pellucida, which strongly resembles a basal lamina, can be continuously regenerated, rendering its filtering function highly efficient during the crucial stages of follicular development and oocyte growth.

No matter what their functions may be, when these follicle extensions are fully revealed by SEM, they definitely contribute to the tremendous expansion of the surface area of corona cells and their contact with the oocyte. They thus mediate an incredible movement of substances (molecules and ions) in these areas not only from the follicular cells to the oocyte and zona but also in the opposite direction.

A number of SEM studies on the "in situ" and isolated zona pellucida (i.e. after removing corona cells) clearly showed that its structure is pervaded by a large number of tunnel-like interconnected channels which are continuous from the outer to the inner boundary of the zona (MOTTA and VAN BLERKOM, 1974; Phillips and Shalgi, 1980; FAMiliari et al.,
1988, 1989, 1992; NotTolA et al., 1991; PhilliPS, 1991; SathanANTHAN et al., 1993). This pattern, looks somewhat like the complex network formed by bone canaliculi after removing the osteocytes and their long microvillous projections (BONUCCI, 1990).

The narrow spaces separating the dense wall of these zona channels from the surface of cytoplasmic processes countained therein form a kind of microlabyrinthine system of fissures. Here both oocyte and follicular cell metabolic movement can take place. In addition, it is worth noting that follicular cells are highly pulsatile in nature as demonstrated by the presence of contractile filament bundles within their cortical cytoplasm and cellular extensions (MоTTA and DiDio, 1974; MOTTA and VAN BLERKOM, 1975; AMSTERDAM et al., 1991; SATHANANTHAN et al., 1986; 1993). Therefore, due to this motility, not only are they probably able to establish initial contact with the oocyte (HERTIG and ADAM, 1967; ZAMBONI, 1971; SATHANANTHAn et al., 1986), but later they were shown to be capable of retracting their extensions from the oocyte prior to ovulation (ZAMBONI, 1974; MotTA and VAN BLERKom, 1975).

Consequently, the obvious deduction is that, in the living state, the cytoplasmic extensions of follicular cells may expand and retract continuously by discrete pulsatile movements within the microchannels which are in a sense "sculptured" in the thick and solidified zona pellucida. Therefore, the contact which many of them establish with the oocyte may not be permanent, but on the contrary, must be regarded as being very dynamic (Figs. 30, 31). If this mechanism really operates in vivo as predicted, it must be highly advantageous. In fact, by creating a variety of dynamic contacts between: a) follicular cells and oocyte and b) among cytoplasmic projections of cumulus corona cells, it in turn may serve to actively modulate (stimulating or inhibiting) the coordination of the follicle-oocyte complexes.

\section{REFERENCES}

Albertini, D. F. and E. Anderson: The appearance and structure of intercellular connections during the ontogeny of the rabbit ovarian follicle with particular reference to gap junction. J. Cell Biol. 63: 234-250 (1974).

Amsterdam, A. and S. Rotmensch: Structure-function relationship during granulosa cell differentiation. Endocrinol. Rev. 8: 309-338 (1987).

Amsterdam, A., B. S. Suh, S. Himmelhoch, G. Baum and A. BEN-ZE'Ev : Modulation of granulosa cell ultrastructure during differentiation: the role of the cytoskeleton. In: (ed. by) G. FAMILIARI, S. MAKABE and P. M. MotTA: Ultrastructure of the ovary (Series in Electron 
Microscopy in Biology and Medicine, 9). Kluwer Academic Publishers, Boston, 1991 (p. 101-112).

BACA, M. and L. ZAMBoni: The fine structure of human follicular oocytes. J. Ultrastr. Res. 19: 354-381 (1967).

BAKER, T. G.: Oogenesis and ovulation. In: (ed. by) C. R. AUSTIN and R. V. SHORT: Reproduction in mammals. I. Germ cells and fertilization. 2nd ed. Cambridge University Press, 1982 (p. 17-45).

Baker, T. G. and L. L. Franchi: The fine structure of oogonia and oocytes in human ovaries. J. Cell Sci. 2; 213-224 (1967).

BonuccI, E.: The ultrastructure of the osteocyte. In: (ed. by) E. BonUCCI and P. M. MotTA: Ultrastructure of skeletal tissue. Bone and cartilage in health and disease (Series in Electron Microscopy in Biology and Medicine, 7). Kluwer Academic Publishers, Boston, 1990 (p. 223-238)

Chiquoine, A. D.: The development of the zona pellucida of the mammalian ovum. Amer. J. Anat. 106: 149-169 (1960).

Dvorak, M. and J. Tesarik: Ultrastructure of human ovarian follicles. In: (ed. by) P. M. MotTA and E. S. E. HAFEZ: Biology of the ovary. Martinus Nijhoff Publishers, The Hague, 1980 (p. 121-137).

EPPIG, J. J.: The relationship between cumulus celloocyte coupling oocyte meiotic maturation, and cumulus expansion. Devel. Biol. 89: 268-272 (1982).

Familiari, G., S. A. Nottola, G. Micara, C. Aragona and P. M. MotTA: Is the sperm binding capability of the zona pellucida linked to its surface structure? A scanning electron microscopic study of human in vitro fertilization. J. in Vitro Fertil. Embryo Transf. 5: 134143 (1988).

Familiari, G., S. MaKabe and P. M. MotTa: The ovary and ovulation. A three-dimensional ultrastructure study. In: (ed. by) J. VAN BLERKOM and P. M. MotTA: Ultrastructure of human gametogenesis and early embryogenesis (Series in Electron Microscopy in Biology and Medicine, 5) Kluwer Academic Publishers, Boston 1989 (p. 85-124).

Familiari, G., S. A. Nottola, G. Macchiarelli, G. Micara, C. Aragona and P. M. Motta: Human zona pellucida during in vitro fertilization: an ultrastructural study using saponin, ruthenium red, and osmium-thiocarbohydrazide. Molec. Reprod. Devel. 32: 51-61 (1992).

FawcetT, D. W.: The cell. 2nd ed. W. B. Saunders Company, Philadelphia, 1981.

GILULA, N. B.: Gap junctions and cell communication. In: (ed. by) B. R. BRINKLEY and K. R. PORTER: International cell biology. Rockfeller University Press, New York 1977 (p. 61-69).

Gougeon, A.: Follicular growth to ovulation. In: (ed. by) R. G. EDWARDS: Establishing a successful human pregnancy (Serono Symposia, Vol. 66). Raven Perss, New York, 1990 (p. 49-62).

GURAYA, S. S.: Biology of ovarian follicles in mammals. Springer Verlag, Heidelberg, 1985.

Hertig, A. T. and E. C. Adams Studies on the human oocyte and its follicle. I. Ultrastructural and histo- chemical observations on the primordial follicle stage. J. Cell Biol. 34: 647-675 (1967).

Hope, J.: The fine structure of the developing follicle of the Rhesus ovary. J. Ultrastr. Res. 12: 592-610 (1965).

Hope, J., A. A. Humphries, Jr. and G. H. Bourne: Ultrastructural studies on developing oocytes of the Salamander Triturus viridescens. The relationship between follicle cells and developing oocyte. J. Ultrastr. Res. 9: 302-324 (1963).

Larsen, W. L., S. E. Wert and G. D. Brunner: Differential modulation of cell gap junction population at ovulation. Devel. Biol. 122: 61-71 (1987).

Macchiarelli, G., S. A. Nottola, E. Vizza, T. Kikuta, T. Murakami and P. M. Motta: Ovarian microvasculature in normal and hCG stimulated rabbits. A study of vascular corrosion cast with particular regard to the interstitium. J. Submicrosc. Cytol. Pathol. 23: 391-395 (1991).

Makabe, S., S. A. Nottola and P. M. Motta: Life history of the female germ cells: ultrastructural aspects. In: (ed. by) J. VAN BLERKOM and P. M. MOTTA: Ultrastructure of human embryology and early gametogenesis (Series in Electron Microscopy in Biology and Medicine, 5). Kluwer Academic Publishers, Boston, 1989 (p. 33-60).

Makabe, S., T. Naguro and P. M. Motta: A new approach to the study of ovarian follicles by scanning electron microscopy and ODO maceration. Arch. Histol. Cytol. 55. Suppl.: 83-190 (1992).

MotтA, P. M.: Sulla presenza al microscopio elettronico di ciglia e centrioli in cellule della granulosa ovarica di Lepus cuniculus (Limn.). Bollet. Soc. Ital. Biol. Speriment. 71: 31-35 (1965).

Motta, P. M., Z. Takeva and E. Nesci: Etude ultrastructurale et histochimique des rapports entre les cellules folliculaires et l'ovocyte pendant le développement du follicle ovarien chez les mammifères. Acta Anat. 80: 537-562 (1971a).

Motta, P. M., Z. Takeva and D. Palermo: On the presence of cilia in different cells of the mammalian ovary. Acta Anat. 78: 591-602 (1971b).

MotTA, P. M. and L. J. A. DiDio: Microfilaments in granulosa cells during the follicular development and transformation in corpus luteum in the rabbit ovary. J. Submicrosc. Cytol. 6: 15-27 (1974).

MotTA, P. M. and J. VAN BLERKoM: A scanning electron microscopic study of the luteo-follicular complex. I. Follicle and oocyte. J. Submicrosc. Cytol. 6: 297-310 (1974).

- : A scanning electron microscopic study of the luteo-follicular complex. II. Events leading to ovulation. Amer. J. Anat. 143: 241-264 (1975). : Structure and ultrastructure of ovarian follicles. In: (ed. by) E. S. E. Hafez: Human ovulation. Elsevier/North Holland Biomedical Press, Amsterdam, 1979 (p. 17-38).

- Scanning electron microscopy of the mammalian ovary. In: (ed. by) P. M. MotTA and E. S. E. Hafez): Biology of the ovary. Martinus Njihoff Publishers, The Hague, (p. 162-175) 1980. 
MotTa, P. M. and S. Makabe: Morphodynamic changes of the mammalian ovary in normal and some pathological conditions. A scanning electron microscopic study. Biomed. Res. 2, Suppl.: 325-339 (1981).

MotTa, P. M. and S. MaKabe: Development of the ovarian surface and associated germ cells in the human fetus. A correlated study by scanning and transmission electron microscopy. Cell Tiss. Res. 226: 493-510 (1982).

Motta, P. M., S. A. Nottola, G. Familiari, G. MaCCHIARELLI and E. VizzA: Follicular structures; an ultrastructural study by scanning and transmission electron microscopy and correlated techniques. In: (ed. by) O. N. Sjoberg L. HAMBerger, P. O. JANSON, Ch. OWMAN and H. J. T. Coelingh BenNink: Local regulation of ovarian function. The Parthenon Publishing Group, Lancs, New Jersey, 1992 (p. 39-53).

Murakami, M., T. Shimada, C. I. Huang and I. Obaya SHI: Scanning electron microscopy of epididymal ducts in the Japonese monkey (Macacus fuscata) with special reference to the architectural analysis of stereocilia. Arch. Histol. Jap. 38: 101-107 (1975).

Murakami, T., Y. Ikebuchi, A. Ohtsuka, A. Kikuta, T. TAGUCHI and O. OTHANI: The blood vascular wreath of the rat ovarian follicle, with special reference to its changes in ovulation and luteinization: a scanning electron microscopic study of corrosion casts. Arch. Histol. Cytol. 51: 299-313 (1988).

Nottola, S. A., G. Familiari, G. Micara, C. Aragona and P. M. MotTa: The ultrastructure of human cumulus-corona cells at the time of fertilization and early embryogenesis. A scanning and transmission electron microscopic study in an in vitro fertilization program. Arch. Histol. Cytol. 54: 145-161 (1991).

Pedersen, T. and H. Peters: Proposal for a classification of oocytes and follicles in the mouse ovary. J. Reprod. Fertil. 17: 555-557 (1968).

Phillips, D. M.: Structure and function of the zona pellucida. In: (ed. by) G. FAMILIARI, S. MAKABE and P. M. MotTA: Ultrastructure of the ovary (Series in Electron Microscopy in Biology and Medicine, 9). Kluwer Academic Publishers, Boston, 1991 (p. 63-72).

Phillips, D. M. and R. M. Shalgi: Surface architecture of the mouse and hamster zona pellucida and oocyte. J. Ultrastr. Res. 72: 1-12 (1980).
REYNoLDS, E. S.: The use of lead citrate at high $\mathrm{pH}$ as an electron opaque stain in electron microscopy. J. Cell Biol. 17: 208-212 (1963).

Sathananthan, H. A., Trounson and C. Wood: Atlas of fine structure of human sperm penetration, eggs and embryos cultured in vitro. Praeger Publishers, New York, 1986.

Sathananthan, H., S. C. NG, A. Bongso, A. Trounson and S. RATNAM: Visual atlas of early human development for assisted reproductive technology. University of Singapore Press, 1993.

Sotelo, J. and K. R. Porter: An electron microscopic study of the rat ovum. J. Biophys. Biochem. Cytol. 5: 327-342 (1959).

Tanaka, K. and T. Naguro: High resolution scanning electron microscopy of cell organelles by a new specimen preparation method. Biomed. Res. 2: 63-70 (1981).

VAN BLERKom, J. and P.M. MotTa: The cellular basis of mammalian reproduction. Urban and Schwarzemberg, Baltimore-Munich, 1979.

WARTENBERG, H.: Elektronenmikroskopische und histochemische Studien Über die Oogenese der Amphibieneizelle. Z. Zellforsch. 58: 427-486 (1962).

W ARTENBERG, H. and H. E. STEGNER: Über die elektronemikroscopische Feinstruktur der menschlichen Ovarialeies. Z. Zellforsch. 52: 427-486 (1960).

Watson, M. L.: Staining of tissue sections for electron microscopy with heavy metals. J. Biophys. Biochem. Cytol. 4: 175-177 (1958).

ZAmboni, L.: Fine morphology of mammalian fertilization. Harper and Row, New York, 1971.

: Fine morphology of the follicle wall and follicle cell-oocyte association. Biol. Reprod. 10: 125-149 (1974).

Prof. P. M. MotTA

Department of Anatomy

Faculty of Medicine

University of Rome "La Sapienza"

Via A. Borelli, 50-00161 Rome

Italy

Tel./Fax 06-445 2349 